\title{
ULTIMATE STRENGTH OF T-SHAPED SOCKET JOINTS BETWEEN STEEL BEAM AND CONCRETE-FILLED STEEL TUBULAR COLUMN
}

\author{
Masato YAMADA ${ }^{1}$, Atsushi HAYASHI ${ }^{2}$ and Shin-ichiro NOZAWA ${ }^{3}$ \\ ${ }^{1}$ Member of JSCE, East Japan Railway Company, Research and Development Center \\ (2-0 Nishincho, Kita-ku, Saitama-shi, Saitama 331-8513, Japan) \\ E-mail:ma-yamada@jreast.co.jp \\ ${ }^{2}$ East Japan Railway Company, Research and Development Center \\ (2-0 Nishincho, Kita-ku, Saitama-shi, Saitama 331-8513, Japan) \\ E-mail:a-hayashi@jreast.co.jp \\ ${ }^{3}$ Fellow Member of JSCE, East Japan Railway Company, Research and Development Center \\ (2-0 Nishincho, Kita-ku, Saitama-shi, Saitama 331-8513, Japan) \\ E-mail:s-nozawa@jreast.co.jp
}

\begin{abstract}
As a method of connecting two concrete-filled circular steel tubular constructions, a simple socket joint in which a small diameter tube is inserted with the specific length to a large diameter tube with concrete filling the gap between two tubes has been proposed as an economical and effective joint connection.

The T-shaped joint specimens which differed in parameters such as the path of the shear connector on tube faces and the plate welded to the small diameter tube, thickness of a large diameter tube, length of a large diameter tube, etc. were tested in order to investigate the failure mechanism and the ultimate strength of the joint connection. In this paper, we propose the equation for calculating the ultimate strength.
\end{abstract}

Key Words : concrete-filled steel tube, joint, ultimate strength, shear connector, diaphragm

\section{INTRODUCTION}

In recent years, there have been increasing numbers of railway construction projects subject to various constraints, such as difficult site working conditions, limited working hours and environmental issues. Such projects include rail viaducts above tracks for continuous multi-level configurations in urban areas, viaducts close to tracks, artificial ground construction above tracks and subway construction within railway station buildings. There has been a strong need for structures able to improve construction efficiency, ensure safety and shorten construction period under such constraints. At the same time, structures must be highly economical while providing earthquake resistance sufficient to bear major seismic events. Under such circumstances, the concrete-filled steel tube structure, which forms an integral structure from steel tubes filled with

This paper is translated into English from the Japan paper, which originally appeared on J.Struct. Mech. Earthquake Eng., JSCE,No.759/ I -67,pp.293-308, 2004.4. concrete, is an effective structural solution, because it offers earthquake resistance due to its large load bearing resistance and superior deformation performance, and because the steel tube serves as formwork when the concrete is poured, thereby improving construction safety while simplifying, rationalizing and accelerating the construction process ${ }^{11}$.

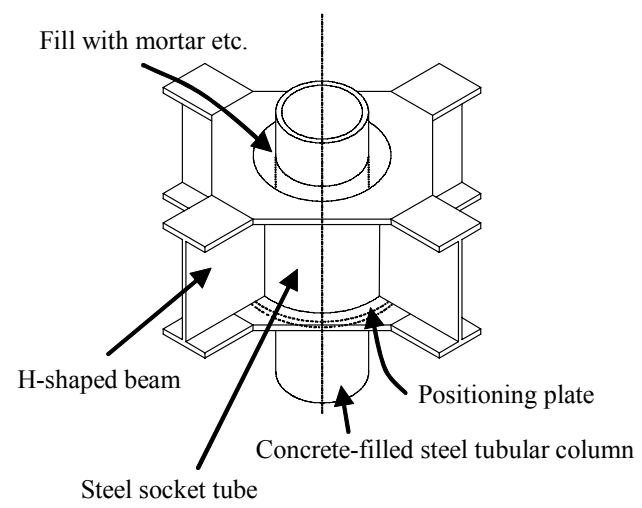

Fig.1 Overview of the Joint 
Table 1 Specification of Specimens

\begin{tabular}{|c|c|c|c|c|c|c|c|c|c|l|}
\hline $\begin{array}{c}\text { Specimen } \\
\text { name }\end{array}$ & $\begin{array}{c}\text { Steel tube } \\
\text { column } \\
\mathrm{d} \\
(\mathrm{mm})\end{array}$ & Beam & $\begin{array}{c}\text { Steel socket } \\
\text { tube diameter } \\
\mathrm{Dm}) \\
(\mathrm{mm})\end{array}$ & $\begin{array}{c}\text { Steel socket } \\
\text { tube length } \\
\mathrm{L} \\
(\mathrm{mm})\end{array}$ & $\begin{array}{c}\text { Steel socket } \\
\text { tube thickness } \\
\mathrm{t} \\
(\mathrm{mm})\end{array}$ & $\mathrm{D} / \mathrm{t}$ & $\mathrm{D} / \mathrm{d}$ & $\mathrm{D} / \mathrm{L}$ & $\mathrm{L} / \mathrm{d}$ & Parameters \\
\hline $\mathrm{P}-1$ & $\phi 318 \times \mathrm{t} 25$ & $\begin{array}{c}\mathrm{H} 350 \times 350 \\
\times 16 \times 22\end{array}$ & 406 & 350 & 6 & 67.7 & 1.28 & 1.16 & 1.10 & Standard case \\
\hline $\mathrm{P}-2$ & $\phi 318 \times \mathrm{t} 25$ & $\begin{array}{c}\mathrm{H} 350 \times 350 \\
\times 16 \times 22\end{array}$ & 500 & 350 & 6 & 83.3 & 1.57 & 1.43 & 1.10 & Steel socket tube diameter \\
\hline $\mathrm{P}-3$ & $\phi 318 \times \mathrm{t} 25$ & $\begin{array}{c}\mathrm{H} 500 \times 350 \\
\times 16 \times 22\end{array}$ & 406 & 500 & 6 & 67.7 & 1.28 & 0.81 & 1.57 & Steel socket tube length \\
\hline $\mathrm{P}-4$ & $\phi 318 \times \mathrm{t} 25$ & $\begin{array}{c}\mathrm{H} 350 \times 350 \\
\times 16 \times 22\end{array}$ & 406 & 350 & 12 & 33.8 & 1.28 & 1.16 & 1.10 & Steel socket tube thickness \\
\hline $\mathrm{P}-5$ & $\phi 318 \times \mathrm{t} 25$ & $\begin{array}{c}\mathrm{H} 350 \times 350 \\
\times 16 \times 22\end{array}$ & 374 & 350 & 6 & 62.3 & 1.18 & 1.07 & 1.10 & Steel socket tube diameter \\
\hline $\mathrm{P}-6$ & $\phi 318 \times \mathrm{t} 25$ & $\begin{array}{c}\mathrm{H} 350 \times 350 \\
\times 16 \times 22\end{array}$ & 406 & 350 & 6 & 67.7 & 1.28 & 1.16 & 1.10 & No positioning plate \\
\hline $\mathrm{P}-7$ & $\phi 318 \times \mathrm{t} 25$ & $\begin{array}{c}\mathrm{H} 350 \times 350 \\
\times 16 \times 22\end{array}$ & 406 & 350 & 6 & 67.7 & 1.28 & 1.16 & 1.10 & $\begin{array}{l}\text { No positioning plate, } \\
\text { no shear connectors }\end{array}$ \\
\hline $\mathrm{P}-8$ & $\phi 318 \times \mathrm{t} 25$ & $\begin{array}{c}\mathrm{H} 350 \times 350 \\
\times 16 \times 22\end{array}$ & 636 & 350 & 6 & 106.0 & 2.00 & 1.82 & 1.10 & Steel socket tube diameter \\
\hline
\end{tabular}

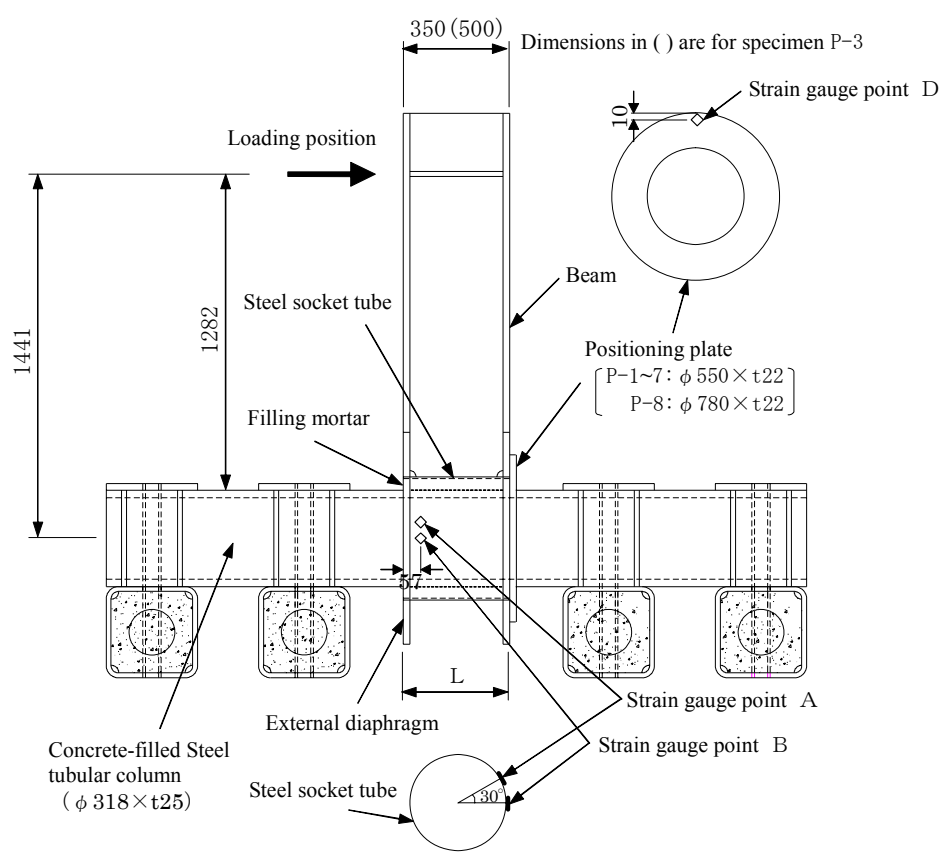

Detail of joint

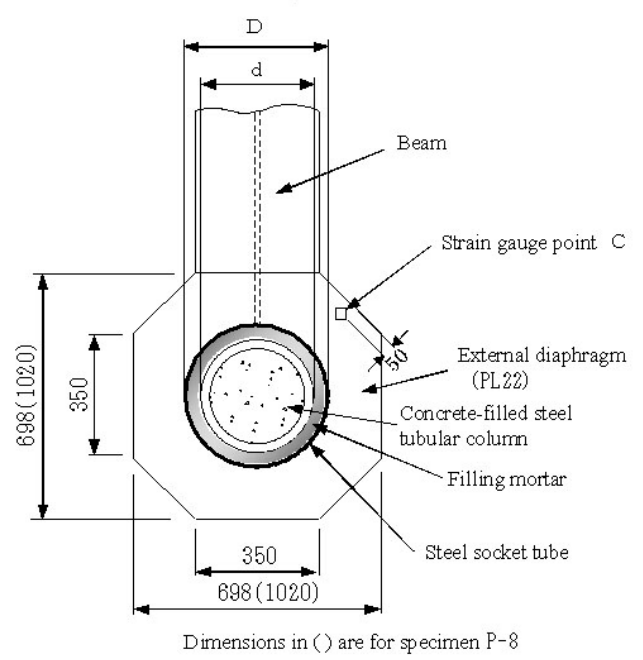

There is a increasing number of the application of concrete-filled steel tube structures to railway structures $^{2) \sim 9)}$. The locations in which such structures have been used are diverse, including columns ${ }^{2)} \sim 6$ ), beams ${ }^{7}$ and the arch ribs for arched bridges ${ }^{8), 9}$. Their application to steel tube trusses ${ }^{10)}$ is also under consideration. As mentioned above, the scope of application of concrete-filled steel tube structures is expanding, and their use is expected to increase in future.

Where concrete-filled steel tubes are used as columns, the structures are commonly mixed structural systems ${ }^{11}$. When concrete-filled steel tubular columns are used in mixed structural systems, the joint must be able to transmit loads in excess of the full plastic moment of the concrete-filled steel tubular column, if the superior element performance of the column is to be fully realized. Thus, the joints in a mixed structural system which combines disparate members are extremely important members for

developing earthquake resistance performance in the structure as a whole.

The joints can be broadly classified into column footings and beam-column joints. For column footings, the anchor frame method, the embedded type and the socket type are used. Such footings have been the subject of extensive research ${ }^{12)} \sim$ 14) in recent years.

A large number of experimental studies in the architecture field have been carried out to date on beam-column joints, and their results are reflected in design standards ${ }^{15}$. There has also been extensive study into beam-column joints in the civil engineering field ${ }^{16)} \sim 19$ ). Socket, embedded and diaphragm types have been proposed as forms of beam-column joint. In addition, the following socket-type joints have been proposed:

(i) A small diameter tube with a specific length is inserted into a large diameter tube with an external diaphragm, with the resulting annular space being 


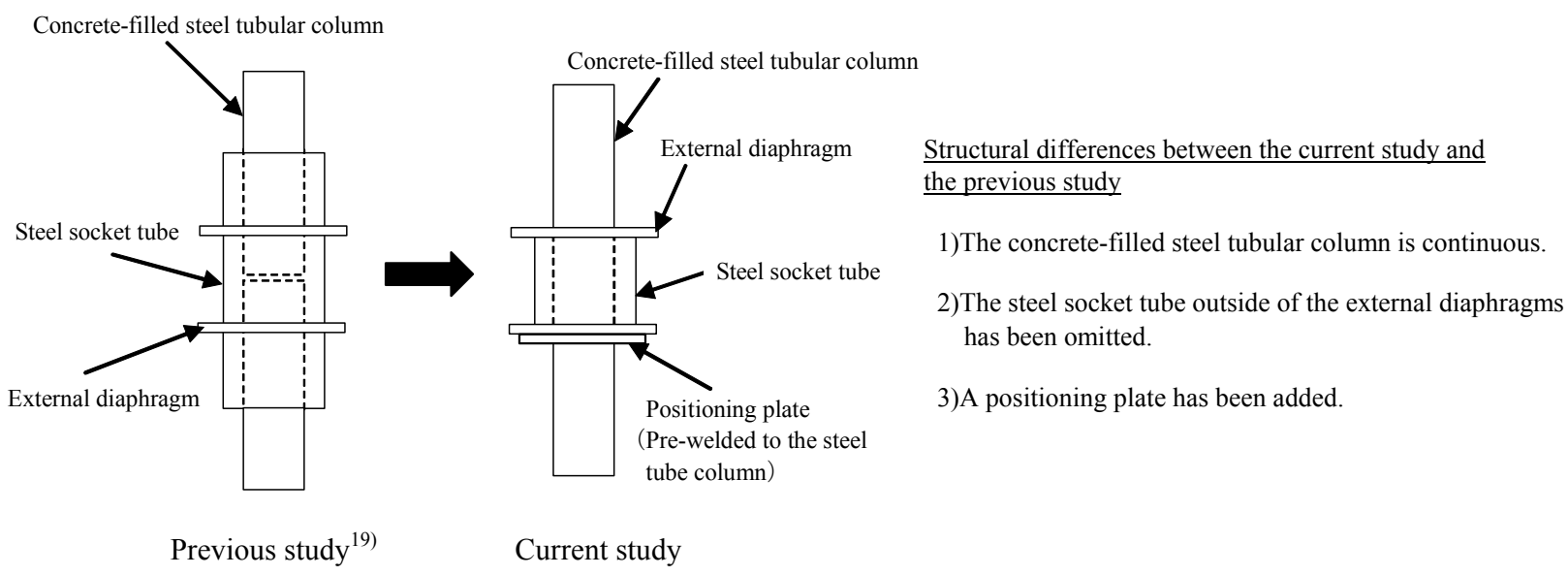

Fig.3 Structural Differences between the Current study and the Previous Study

Table 2 Material Strengths

\begin{tabular}{|c|c|c|c|c|c|c|c|c|}
\hline \multirow{2}{*}{$\begin{array}{c}\text { Specimen } \\
\text { name }\end{array}$} & \multicolumn{4}{|c|}{$\begin{array}{c}\text { Yield point } \\
\left(\mathrm{N} / \mathrm{mm}^{2}\right)\end{array}$} & \multicolumn{2}{c|}{$\begin{array}{c}\text { Compressive strength } \\
\left(\mathrm{N} / \mathrm{mm}^{2}\right)\end{array}$} \\
\cline { 2 - 10 } & Steel socket tube & Steel tube column & External diaphragm & Beam flange & Beam web & Positioning plate & Column concrete & Filling mortar \\
\hline P-1 & 313 & 332 & 345 & 347 & 328 & 345 & 36.7 & 45.9 \\
\hline P-2 & 313 & 332 & 345 & 347 & 328 & 345 & 35.8 & 43.7 \\
\hline P-3 & 313 & 332 & 345 & 347 & 328 & 345 & 36.9 & 45.2 \\
\hline P-4 & 276 & 332 & 345 & 347 & 328 & 345 & 39.6 & 43.0 \\
\hline P-5 & 311 & 321 & 366 & 326 & 330 & 366 & 39.2 & 51.5 \\
\hline P-6 & 311 & 321 & 366 & 326 & 330 & - & 41.8 & 51.1 \\
\hline P-7 & 311 & 321 & 366 & 326 & 330 & - & 40.6 & 53.9 \\
\hline P-8 & 311 & 321 & 366 & 326 & 330 & 366 & 39.8 & 52.4 \\
\hline
\end{tabular}

filled with concrete or mortar to form a unitary joint (the "socket type with external diaphragm", see Fig.1).

(ii) A joint structure in which the column and the beam are unified through an insert consisting of a steel frame and reinforcing bar (the "steel frame and reinforcing bar insert type") ${ }^{11), 16)}$.

However, there have been few studies on joint structures using the socket type with external diaphragm ${ }^{18), 19)}$, and the failure mechanisms and the ultimate strength have not been fully explained.

This study carried out the static loading tests using T-shaped joint specimens and modeling the exterior columns of the structure above a track, to investigate the failure mechanisms and the ultimate strength of beam-column joints using the socket type joint with external diaphragm. In this paper, we proposed the equation for calculating the ultimate strength of the joint.

\section{TEST ON T-SHAPED SOCKET JOINTS $^{20)}$}

\section{(1) Summary of test}

a) Form and specifications of the test specimens

The specifications and forms of the specimens are shown in Table 1 and Fig.2, respectively. The specimens are T-shaped models of beam-column joints, comprising a steel socket tube with a larger diameter than the concrete-filled steel tubular column, into which the column is inserted and the space between the socket and column is filled with mortar to unify the structure. An external diaphragm is provided on the outside of the steel socket tube and joined to the H-shaped beam. Fig.3 shows the structural differences between the joint of this specimen and a previous study ${ }^{19)}$. If the concrete-filled steel tubular column is joined within the steel socket tube, as in the previous study, that socket tube must be longer. Therefore, if, for example, the beam is supporting a slab, the external socket would be a greater impediment than the external diaphragm. Also, when a structure as in the previous study is used, the precision of steel tube fabrication on site is a problem, so a way of making construction easier was required. Also, the shear force from the beam is resisted only by friction between the steel tube and the filling mortar, so a method of improving shear resistance was required. The form of the current specimen was determined through consideration of the construction points stated above.

$\mathrm{P}-1$ is the standard specimen, specimens $\mathrm{P}-2$ and P-5 have different steel socket tube diameters, specimen P-3 has a different steel socket tube length 


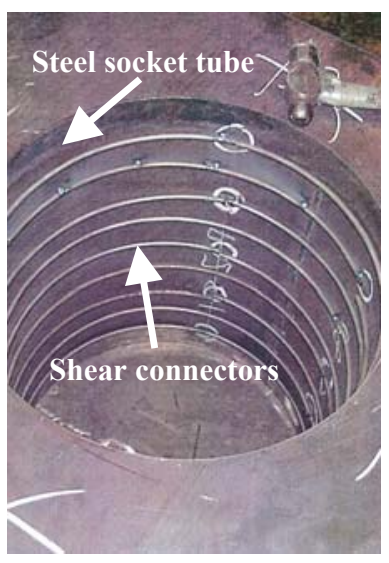

Inner surface of the steel socket tube

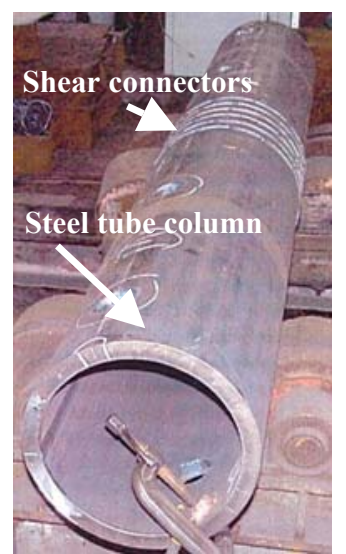

Outer surface of the steel tube column
Fig.4 Arrangemet of Shear Connectors

and specimen P-4 has a different steel socket tube wall thickness. Also, as the plate pre-welded to the steel tube column to resist shear force from the beam and facilitate fabrication ("positioning plate") was expected to impact the strength of the joint, specimen $\mathrm{P}-6$ is a specimen without a positioning plate. The above specimens P-1 to 6 have $\phi 6 \mathrm{~mm}$ steel bars flare welded to the inner surface of the steel socket tube and the outer surface of the steel tube column at $50 \mathrm{~mm}$ pitches ("shear connectors", see Fig.4). These are intended to enhance bonding performance between the surfaces of the steel tubes and the filling mortar. In specimen P-7, the positioning plate and shear connectors are omitted, to investigate the effects of the shear connectors. For specimen P-8, the diameter of the steel socket tube is even larger than for specimen P-2, but, as shown in Fig.2, the outer dimensions of the external diaphragm and the diameter of the positioning plate also differ from the other specimens. In this test, the plate thicknesses for the steel tube column and steel socket tube were chosen so that the joint could be tested to failure without the column yielding.

The steel material is SS400 for the steel socket tube only, with SM490 used for all other elements. The filling concrete for the steel tube column had a design strength of $27 \mathrm{~N} / \mathrm{mm}^{2}$, while the filling material between the column and the steel socket tube was pre-mixed mortar with a design strength of around $45 \mathrm{~N} / \mathrm{mm}^{2}$. Table 2 shows the yield points of the steels used in this test, and the strengths of the concrete and mortar on the day of the test.

\section{b) Loading method}

The loading method is the monotonic static loading at the position shown in Fig.2. Due to the effect of the positioning plate, some variation in the joint strength with loading direction was anticipated, but in this test the aim was to identify the impact on joint strength of parameters such as diameter,

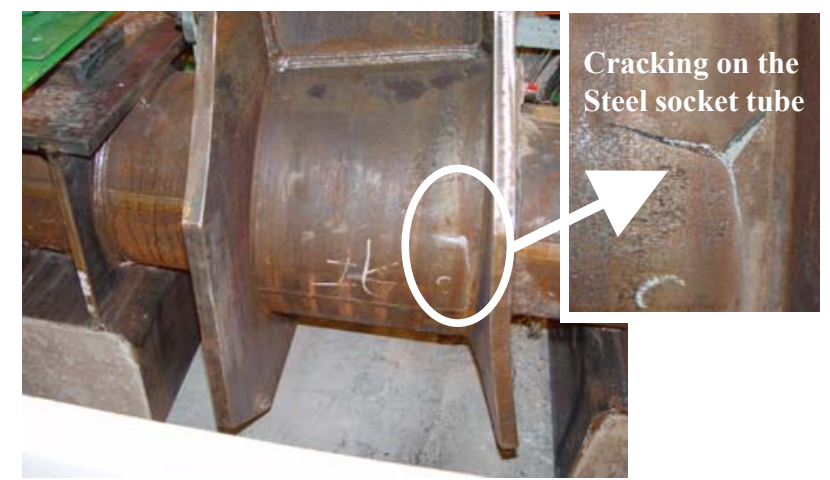

Fig.5 Failure condition of Specimen P-1 (1 of 2)

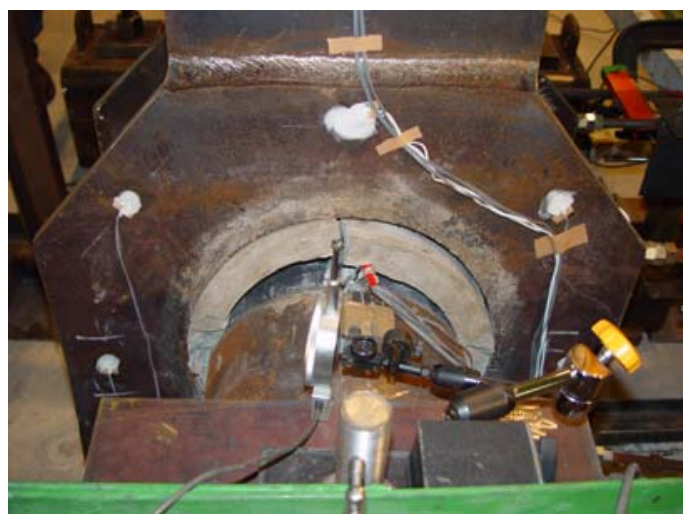

Fig.6 Failure condition of Specimen P-1 (2 of 2)

thickness and length of the steel socket tube, and therefore the loading direction was kept consistent, as shown in Fig.2. Loading was applied until the specimen failed or the jack reached the limit of its stroke (around 200mm).

The measurements were the applied load, displacement of each element and strain in the steel socket tube, steel tube column and external diaphragm.

\section{(2) Test results and observations}

\section{a) Process and properties of failure}

The failure condition of the standard P-1 specimen is described below. First, cracking occurred in the sides of the filling mortar, developing with loading, and voids were observed between the filling mortar, the steel socket tube and the steel tube column. After that, steel socket tube strain gauge point A, as shown in Fig.2, recorded increasing strain on a bearing of $45^{\circ}$ relative to the circumferential direction, reaching yield strain. Further loading caused cracking in the filling mortar to advance, spalling began, and the voids between the mortar, the steel socket tube and the steel tube column widened. Also, the mill scale from the external diaphragm peeled away, and shear deformation of the steel socket tube developed. Then, out-of-plane deformation of the positioning plate and external diaphragm advanced, and the test concluded 


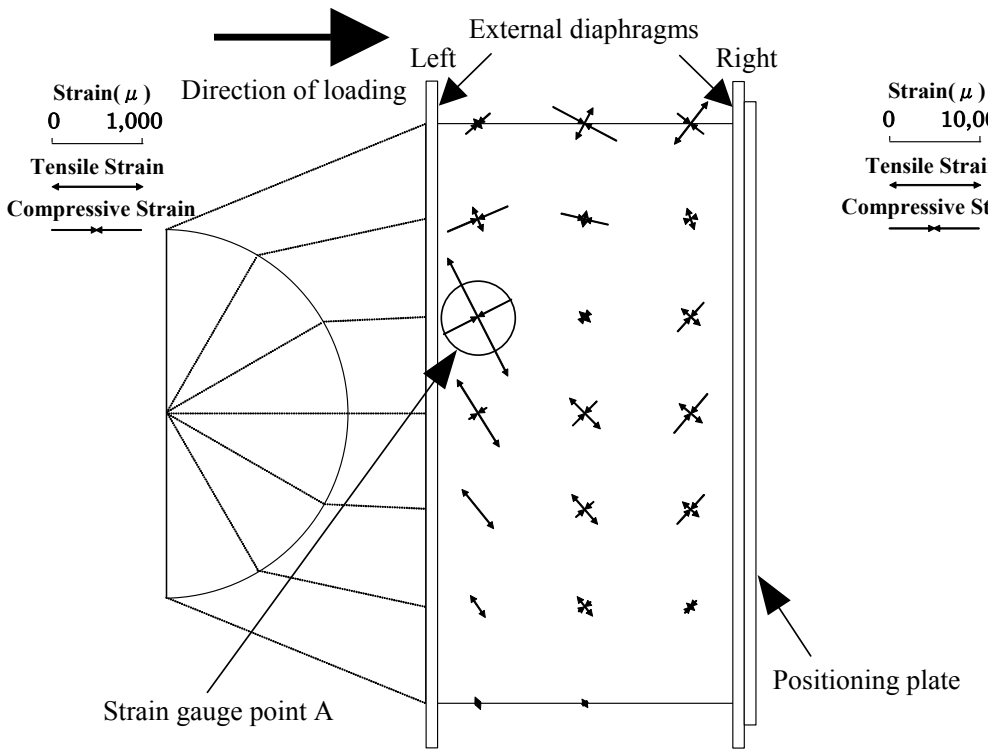

(a) Specimen P-1 at yielding load

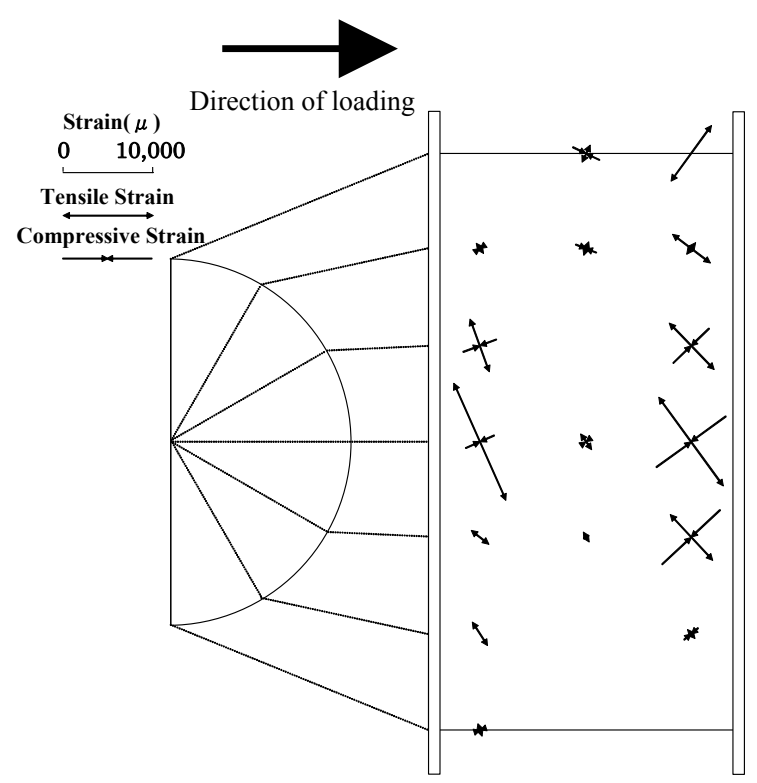

(c) Specimen P-6 at ultimate strength

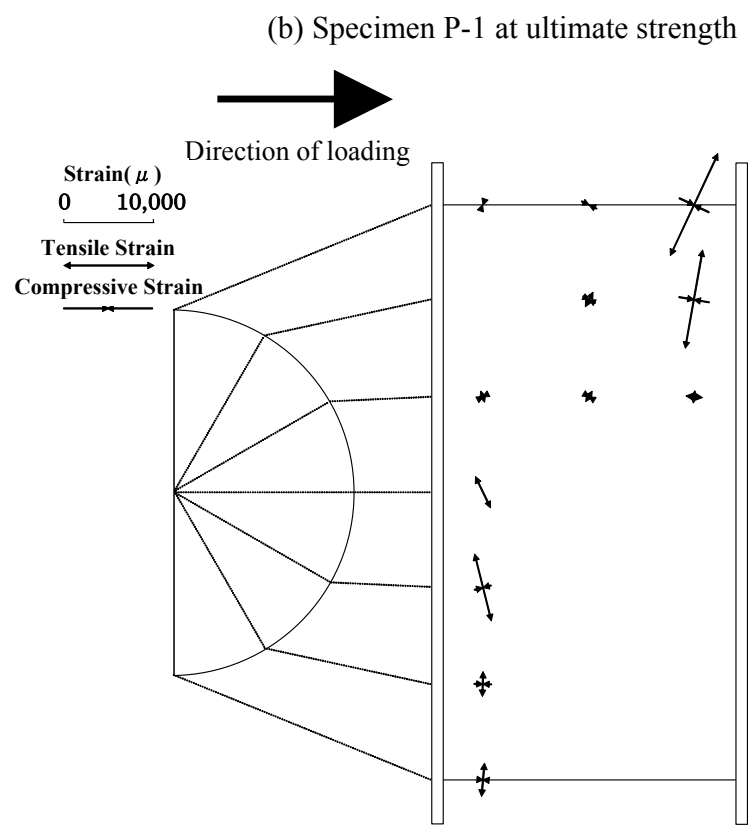

(d) Specimen P-7 at ultimate strength

Fig.7 Principal Strain Distribution in the Steel Socket Tube

when cracking was observed in the side of the steel socket tube. Fig.5 and $\mathbf{6}$ show the failure conditions.

There were some differences between the other specimens in the position and direction which reached yield strain, and the damage processes for each element, but the failure conditions were largely the same as for specimen P-1.

\section{b) Definition of yielding load}

The yielding load for this test is defined as the load when any of the strain gauge points (triaxial gauges at 21 positions) on the surface of the steel socket tube was judged to have yielded, according to the von Mises yield condition (1) for the plane stress state.

$$
\begin{aligned}
\sigma_{\mathrm{Y}}{ }^{2}=\sigma_{1}{ }^{2} & -\sigma_{1} \sigma_{2}+\sigma_{2}{ }^{2} \\
\sigma_{1}, \sigma_{2} & : \text { Principal stress } \\
\sigma_{\mathrm{Y}} & : \text { Tensile yield strength }
\end{aligned}
$$

In this test, all specimens yielded at strain gauge point $A$, with the exception of specimen $\mathrm{P}-7$, which failed at strain gauge point B, as shown in Fig.2.

c)Principal strain distribution on the steel socket tube

Fig.7 shows the principal strain distribution on the surface of the steel socket tube. Fig.7(a) shows the principal strain distribution for specimen P-1 at the yielding load, as defined in the preceding article. 

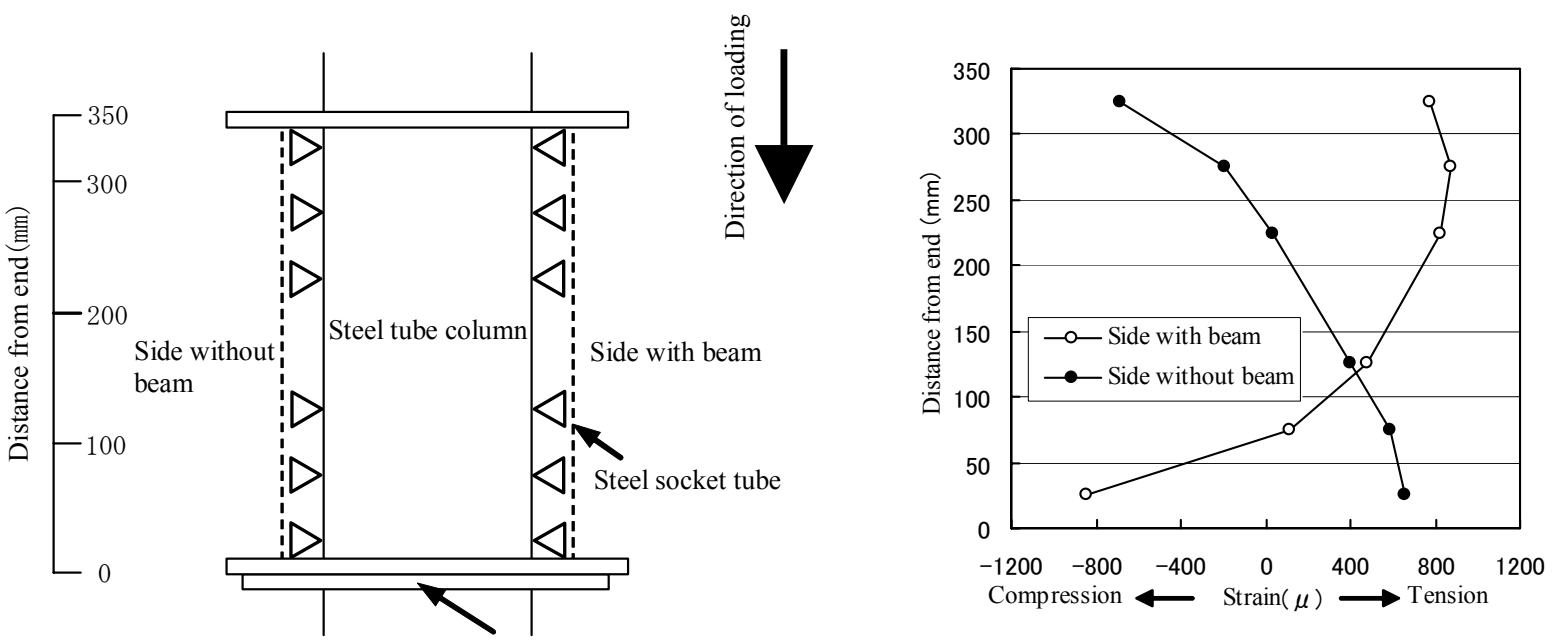

$\triangleright, \triangleleft$ : Strain gauge poBitsötioning plate

(a) Specimen P-1 at ultimate strength
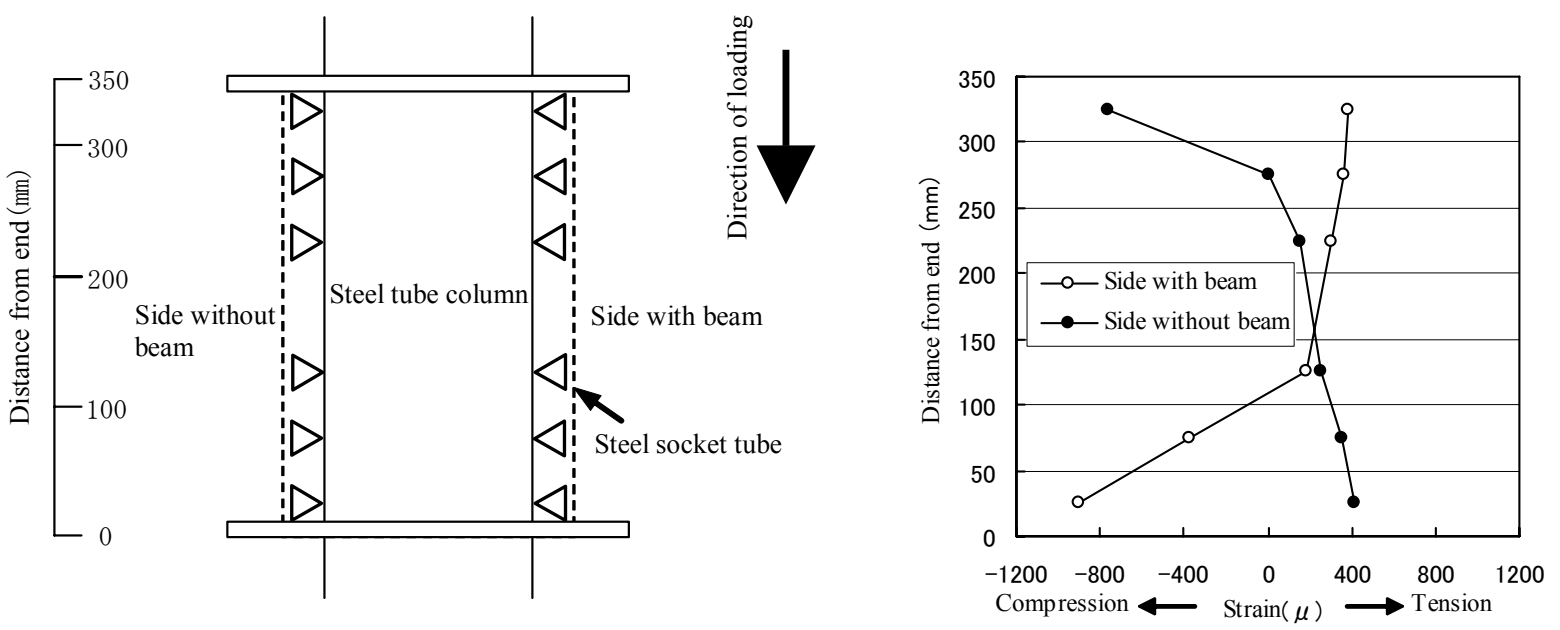

(b) Specimen P-7 at ultimate strength

Fig.8 Strain Distribution in the Steel Tube Column

Fig.7(b) shows the principal strain distribution at the ultimate strength for specimen $\mathrm{P}-1$, as defined in sub-section f) below. Fig.7(c) and (d) show the principal strain distributions at the ultimate strength of specimens P-6 and P-7.

First, for specimen P-1 at the yielding load, Fig.7 (a) shows that shear stress (and inclined tensile strength) of the steel socket tube on the left external diaphragm side is the greatest. Furthermore, Fig.7(b) confirms that this tendency becomes more marked as the imposed load increases. The fact that the shear stress at that point is the highest appears to be the reason for the cracking of the steel socket tube, as shown in Fig.5. The principal strain distribution in the steel socket tube at the ultimate strength in specimen P-6, as shown in Fig.7(c), differs somewhat from that in specimen P-1. It is apparent that, in specimen P-6, the shear stress on the steel socket tube on the right external diaphragm side is close to that on the left external diaphragm side. That is because, in specimen P-1, the constraint imposed by the positioning plate causes a greatly increased shear stress in the steel socket tube on the left external diaphragm side. As there is no constraint from the positioning plate in specimen P-6, the shear stress is approximately equal on the steel socket tube on both the left and right external diaphragm sides. As above, it can be estimated from the figures that the presence or absence of the positioning plate causes some change in the shear stress distribution in the steel socket tube, but the stress flows to the external diaphragm through the steel socket tube. Therefore, it can be estimated that, in specimens P- 1 and P- 6 , the steel socket tube functions effectively as a resistive element in the joint to resist sectional force from the beam.

The principal strain distribution in the steel socket tube at the ultimate strength in specimen P-7, as 
shown in Fig.7(d), differs somewhat from that in the other two specimens. In that case, strain in the steel socket tube in the circumferential direction is the greatest on both the left and right external diaphragm sides. It can be estimated that this result occurred because the lack of shear connectors reduced the bonding force between the surface of the steel socket tube and the filling mortar, meaning that the steel socket tube was less effective than in other tests as a resistive element in the joint to resist sectional force from the beam.

In the other specimens, there were some differences in the shear stress concentration positions, but the principal strain distributions were largely the same as for specimen P-1.

\section{d) Strain distribution in the steel tube column}

Fig.8 shows the strain distribution in the steel tube column. Fig.8(a) and (b) show the principal strain distributions in the steel tube column at the ultimate strength of specimens P-1 and P-7. The figure indicates that the steel tube column receives a largely triangular bearing force distribution from the filling mortar, and that the sectional force from the beam is transmitted to the column through this bearing force. In specimen P-1, the values for compressive strain and tensile strain were largely equal, but in specimen P-7, the compressive strain value was larger. This can be estimated to be due to the differing con- tribution of the steel socket tube as a resistive element in the joint, as explained above.

\section{e) Load-displacement relationships}

Fig.9 shows the load-displacement relationships for specimens P-1 and P-2. Fig.10 shows the relationships between load and shear strain at strain gauge point $\mathrm{A}$ for specimens $\mathrm{P}-1$ and $\mathrm{P}-2$. This shear strain is that in the in-plane direction in the steel socket tube. At the yield points of specimens P-1 and $\mathrm{P}-2$, the directions were clockwise $17.7^{\circ}$ and $15.8^{\circ}$ respectively in the circumferential direction of the steel socket tube. It is clear that the tendency of increasing strain in the load-shear strain relationship shown for specimen P-1 in Fig.10 differs from the tendency of increasing displacement in the loaddisplacement relationship shown for the same specimen in Fig.9. Thus, even if non-linearity emerges after yielding load is reached, there is no clear non-linearity in the load-displacement relationship shown in Fig.9. Fig.11 shows the relationship between load and external diaphragm strain at strain gauge point $\mathrm{C}$ in specimens $\mathrm{P}-1$ and P-2 (see Fig.2). The tendency of increasing strain in the load-strain relationship shown in specimen P-1, as shown in Fig.11, can be seen to largely correspond with the tendency of increasing displacement in the load-displacement relationship shown in Fig.9.

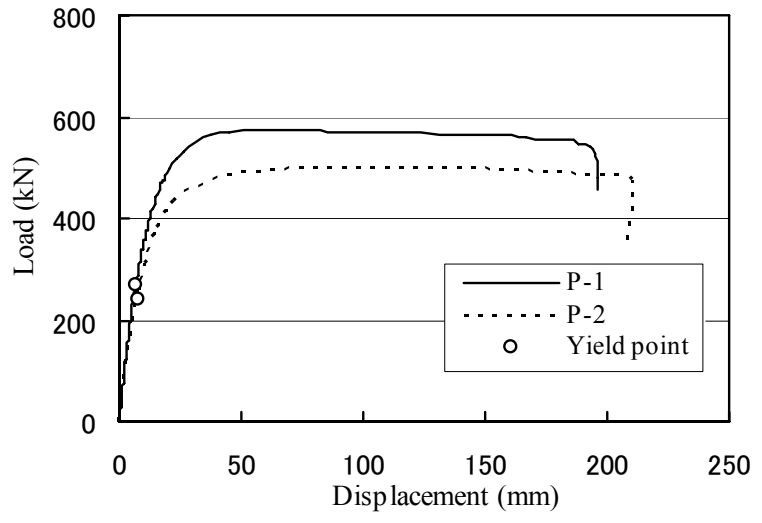

Fig.9 Load-Displacement Relationships

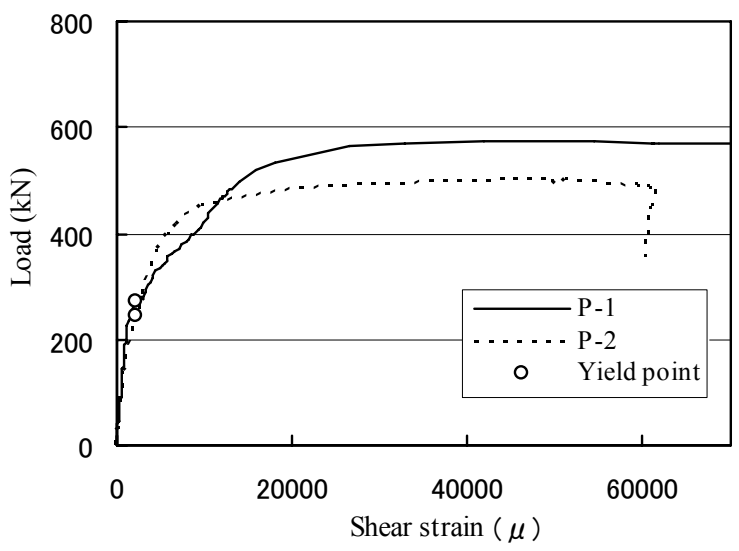

Fig.10 Load-Shear Strain Relationships

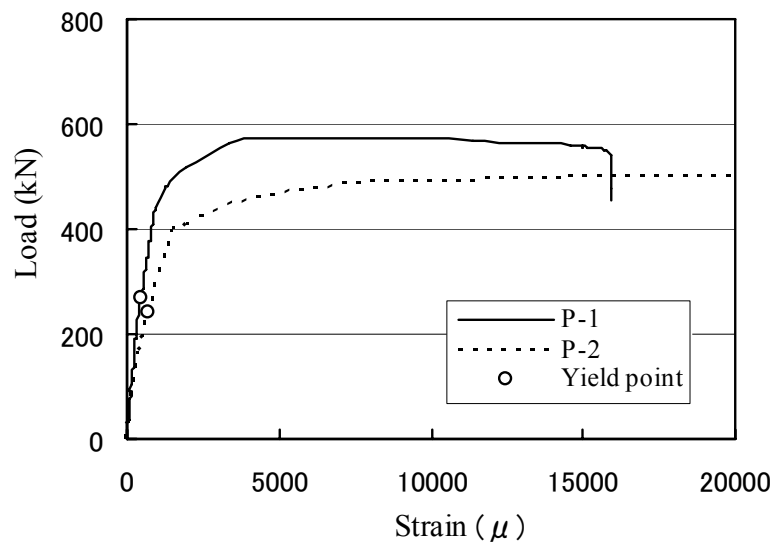

Fig.11 Load-External Diaphragm Strain Relationships

Therefore, it can be estimated that the mode of failure of specimen P-1 is dominated by the tensile yielding of the external diaphragm, rather than by shear yielding of the steel socket tube.

It is clear that, for specimen P-2, which has a larger steel socket tube diameter, the tendency of increasing strain in the load-shear strain relationship shown in Fig.10 corresponds well to the tendency of increasing displacement in the load-displacement relationship shown for the same specimen in Fig.9. Also, Fig.10 and $\mathbf{1 1}$ show that the development of shear strain in the steel socket tube is accompanied by a rapid increase in strain in the external di- aphragm. Therefore, it can be estimated that the mode of failure 


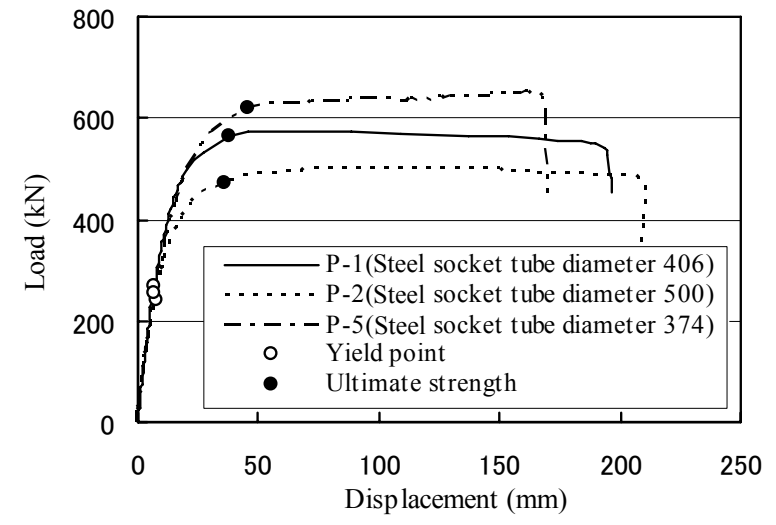

Fig.12 Effect of Steel Socket Tube Diameter (1 of 2)

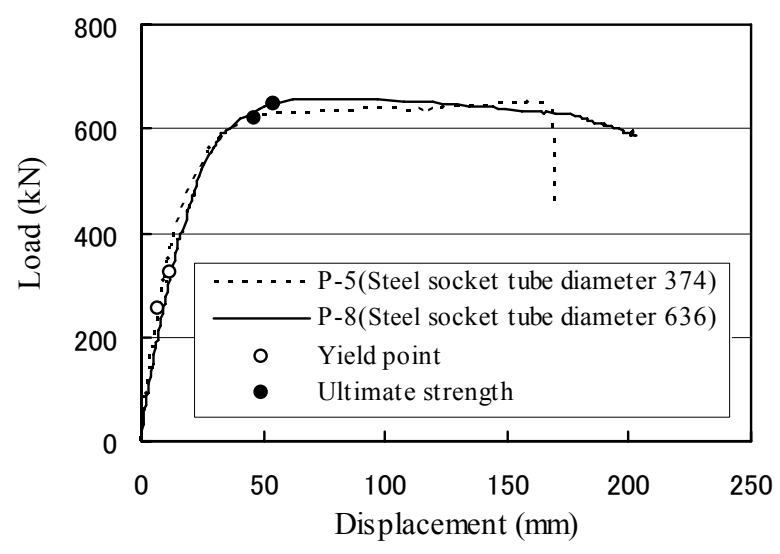

Fig.13 Effect of Steel Socket Tube Diameter (2 of 2)

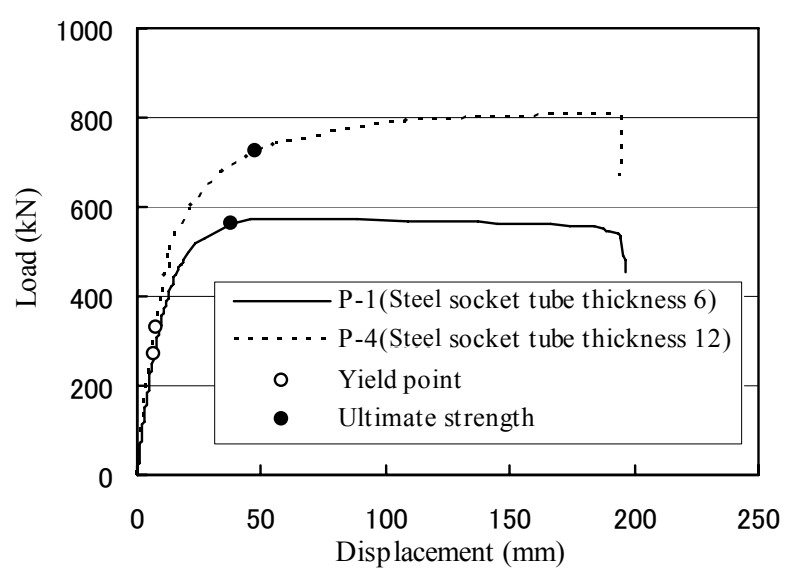

Fig.14 Effect of Steel Socket Tube Thickness

of specimen P-2 is dominated by shear yielding of the steel socket tube. For specimens other than P-2, all but P-8 tended to show largely the same mode of failure as specimen $\mathrm{P}-1$.

\section{f) The effect of each parameter on the load-} displacement relationship

Fig.12 to 16 show the load-displacement relationships for each specimen. Fig.12 and $\mathbf{1 3}$ compare the effect of steel socket tube diameter, Fig.14 the effect of the steel socket tube steel plate thickness, Fig.15 the effect of the positioning plate and shear connectors, and Fig.16 the effect of steel socket tube

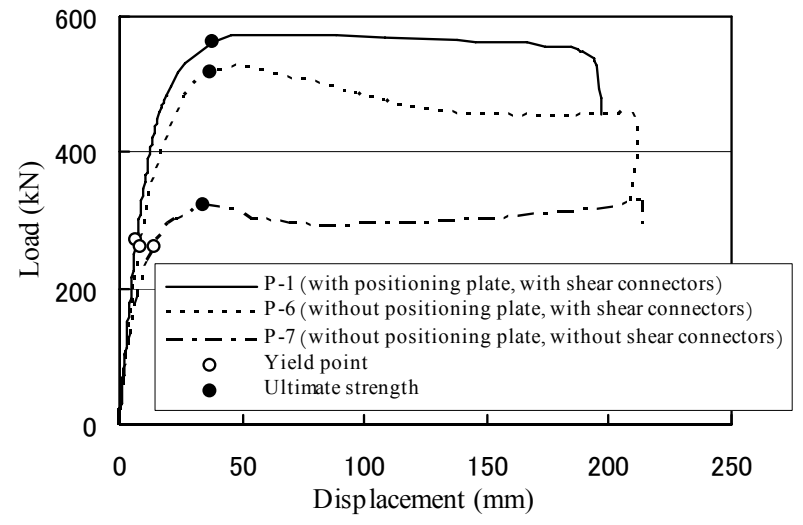

Fig.15 Effect of Positioning Plate and Shear Connectors

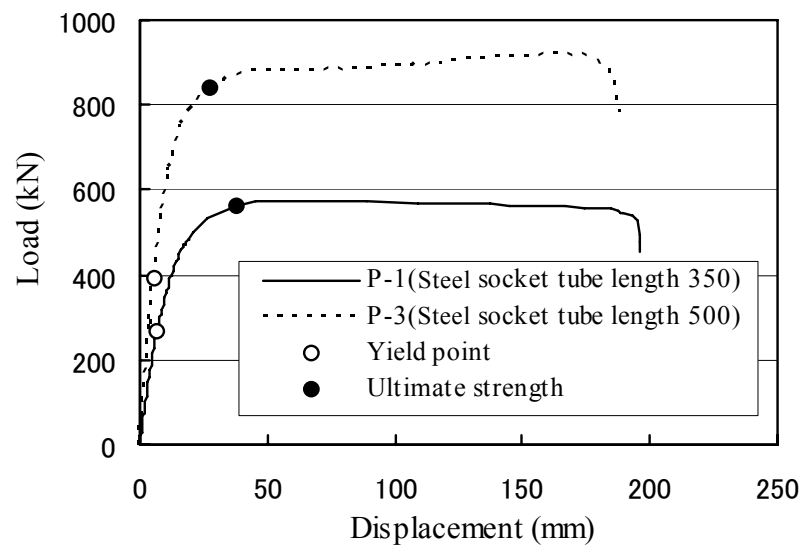

Fig.16 Effect of Steel Socket Tube Length

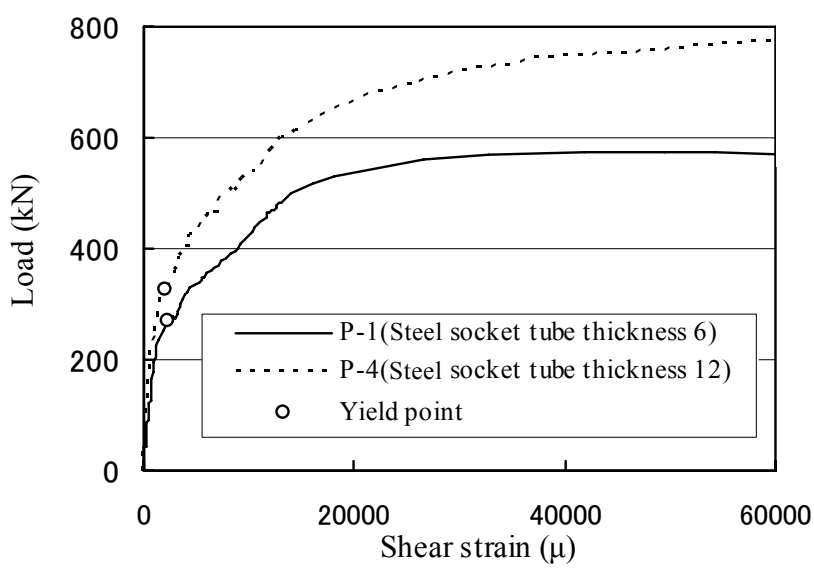

Fig.17 Load-Shear Strain Relationships

length. The marks in the figures represent ultimate strength, as defined below.

As the figures show, for many specimens the loaddisplacement relationships do not show clear load peaks, and load does not show a downward trend even when displacement is quite large. Therefore, it does not seem to be appropriate for design purposes to take maximum load as ultimate strength. Therefore, for convenience, we decided to define ultimate strength found from the test as the load when the gradient of the tangent for load-displacement relationships has fallen to $5 \%$ of the initial gradient. The point defined in this 
way is generally at a strong bend in the load-displacement relationships, after which the proportion of load increase remains low, suggesting that it is appropriate to take the load at that point as the ultimate strength for design purposes ${ }^{13)}$.

- Effect of steel socket tube diameter

In Fig.12, the external dimensions of the external diaphragm and the diameter of the positioning plate are constant (see Fig.2) and the specimens are compared with different steel socket tube diameters. The figure indicates that the ultimate strength tends to decline as the steel socket tube diameter increases. As described above, this is because in this test, when external dimensions of the external diaphragm are fixed, increasing the diameter of the steel socket tube inevitably reduces the area of the external diaphragm, and this appears to reduce strength. As above, the modes of failure for specimens P-1 and P-5 are estimated to be due to tensile yielding of the external diaphragm, and for P-2 is estimated to be due to shear yielding of the steel socket tube. Therefore, one can estimate from the difference between the forms of the steel socket tube and the external diaphragm that the point of transition in the mode of failure lies between the forms of specimens P-1 and P-2.

On the other hand, despite the fact that specimen P-8, shown in Fig.13, has the largest steel socket tube diameter, it has an ultimate strength value larger than for specimen P-5. This is because the external dimensions of the external diaphragm and the diameter of the positioning plate for specimen $\mathrm{P}-8$ (see Fig.2) differ from the three specimens shown in Fig.12, and therefore the external diaphragm and positioning plate had a greater effect on ultimate strength.

- Effect of steel socket tube thickness

The steel socket tube for specimen P-4 was $12 \mathrm{~mm}$ thick, and its ultimate strength was higher than for specimen P-1. The mode of failure for specimens P-1 and $\mathrm{P}-4$ are estimated to be caused by tensile yielding in the external diaphragm, but it would be reasonable to assume that the ultimate strength would be the same for each, as the external diaphragms in each had the same dimensions and strength. However, there was actually a difference between the ultimate strength values of the two, for the reason below.

Fig.17 shows the relationship between load and shear strain at stress gauge point $\mathrm{A}$ in specimens $\mathrm{P}-1$ and P-4 (see Fig.2). The Figure shows that both specimens exhibit non-linearity after reaching yielding load, but beyond that point the loads borne by the steel socket tubes differ due to different plate thicknesses. That difference is estimated to have manifested as a disparity in ultimate strength. This indicates that as the ultimate strength of the joint is

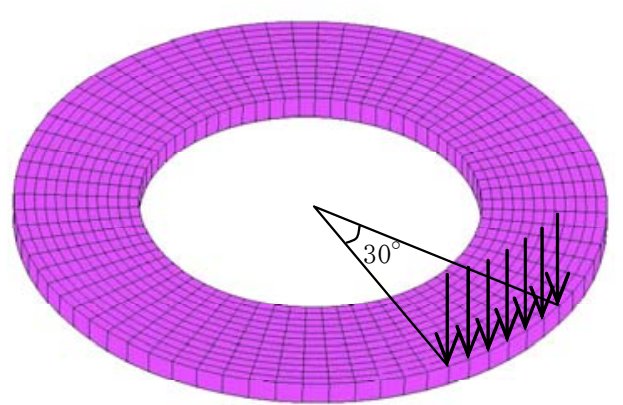

Fig.18 Analytical Method

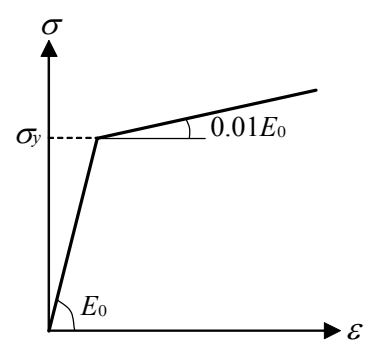

Fig.19 Model of a Stress-Strain Relationship for Steel

due to a load bearing mechanism formed by the interaction of the steel socket tube and the external diaphragm, the mode of failure of the joint is controlled by which has the greater ultimate strength.

- Effect of the positioning plate and the shear connectors

Specimen P-6, which lacks a positioning plate, showed lower initial stiffness and ultimate strength than specimen $\mathrm{P}-1$, which has a positioning plate. This result indicates that the positioning plate has an effect on both stiffness and ultimate strength. Also, the declining trends beyond maximum load differed between the two. This is because even after maximum load, the positioning plate in specimen P-1 continues to bear load as a resistive element, while load declined in specimen P-6, which lacks a positioning plate.

Specimen P-7, which lacks a positioning plate and shear connectors, showed lower initial stiffness and ultimate strength than specimen P-1, which has both elements. In particular, ultimate strength for P-7 is approximately $60 \%$ of that for $\mathrm{P}-1$, which indicates the considerable effect of the shear connectors. Therefore, it can be estimated that the transmission of friction between the filling mortar, the column and the steel socket tube is a major factor in resistance within the load bearing mechanism of the joint.

- Effect of steel socket tube length

As the modes of failure for specimens P-1 and P-3 are estimated to be due to tensile yielding of the external diaphragm, the results for stiffness and ultimate strength were both higher for specimen P-3, which has a longer interval between external diaphragms. 
Table 3 Estimated Load Bearing Strength of the Positioning Plate at the Ultimate Strength

\begin{tabular}{|c|c|c|c|}
\hline $\begin{array}{c}\text { Specimen } \\
\text { name }\end{array}$ & Strain & $\begin{array}{c}\text { Estimated load bearing } \\
\text { strength of the } \\
\text { positioning plate } \\
(\mu)\end{array}$ & Notes \\
\hline $\mathrm{P}-1$ & 140 & 41.2 & \\
\hline $\mathrm{P}-2$ & 160 & 46.2 & \\
\hline $\mathrm{P}-3$ & 20 & 5.9 & \\
\hline $\mathrm{P}-4$ & 130 & 37.8 & \\
\hline $\mathrm{P}-5$ & 110 & 31.9 & \\
\hline $\mathrm{P}-6$ & - & - & No positioning plate \\
\hline $\mathrm{P}-7$ & - & - & No positioning plate \\
\hline $\mathrm{P}-8$ & 600 & 120.0 & \\
\hline
\end{tabular}

\section{CALCULATION OF ULTIMATE STRENGTH FOR T-SHAPED SOCKET JOINTS}

\section{(1) Effect of the positioning plate}

According to the examination of the effect of test parameters in the preceding chapter, the joint had higher ultimate strength when it was equipped with a positioning plate than when it was not. Therefore, we investigated the effect of the positioning plate on the ultimate strength of the joint. This examination used a three-dimensional, non-linear finite element method (FEM) analysis to model the positioning plate. The analytical tool was MARC, a general-purpose finite element method program.

Fig.18 shows the analytical model. The elements were all solid elements. The boundary condition was that the inner circumferential of the positioning plate is fully fixed. A bilinear model, as shown in Fig.19, was used to measure the steel finite elements, based on material test results. In the tests, load was imposed on the positioning plate through its contact with the external diaphragm, but it was difficult to define the range of distribution of that load, or the form of distribution, from the tests. Therefore we employed a simple loading method, as described below, to estimate those properties.

Various loading cases were investigated so that for analysis of a given loading case, the strain gauge reading for the ultimate strength at strain gauge point D (see Fig.2) in the test was matched to the strain value generated by the analysis, and the load from the analysis at that time largely agreed with the estimated load intensity on the positioning plate in the test (difference between experimental ultimate strengths of specimens P-1 and P-6: $46 \mathrm{kN}$ ). The result was that placing a linear load within a $30^{\circ}$ range, as shown in Fig.18, produced largely the same values as the experimental results. Table $\mathbf{3}$ shows the load intensities on the positioning plate at the ultimate strength for each specimen, as estimated by the above loading method.

\section{(2) Comparison between the experimental results and the previous calculation method}

In reference 11), the modes of failure described for a socket with external diaphragm were caused by either tensile yielding of the external diaphragm or shear yielding of the shear panel in the steel socket tube. The ultimate strength calculation method presented for each mode are as follows:

- Calculation method for the ultimate strength of the external diaphragm

$$
M_{\mathrm{u}}=P_{\mathrm{a}} \cdot h_{\mathrm{f}}
$$

where $P_{\mathrm{a}}$ : Axial force in the diaphragm $(\mathrm{kN})$

$h_{\mathrm{f}}:$ External diaphragm interval $(\mathrm{mm})$

$$
\begin{aligned}
P_{\mathrm{a}}= & 1.77 A_{1} \cdot f_{\text {dy }}+1.53 A_{2} \cdot f_{\text {sy }} \\
A_{1} & =h_{\mathrm{s}} \cdot t_{\mathrm{s}} \\
A_{2} & =\left\{\left(0.63+0.88 \frac{B \mathrm{f}}{D}\right) \cdot \sqrt{D \cdot t}+t_{\mathrm{s}}\right\} \cdot t
\end{aligned}
$$

$B_{\mathrm{f}}:$ Beam flange width $(\mathrm{mm})$

$D$ : Steel socket tube external diameter $(\mathrm{mm})$

$f_{\mathrm{dy}}$ : Tensile yielding strength of the external diaphragm $\left(\mathrm{kN} / \mathrm{mm}^{2}\right)$

$f_{\text {sy }}$ : Tensile yielding strength of the steel socket tube $\left(\mathrm{kN} / \mathrm{mm}^{2}\right)$

$h_{\mathrm{s}}:$ Height of the external diaphragm at section $\mathrm{I}-\mathrm{I}(\mathrm{mm})$

$t$ : Steel socket tube plate thickness (mm)

$t_{\mathrm{s}}:$ External diaphragm plate thickness (mm)

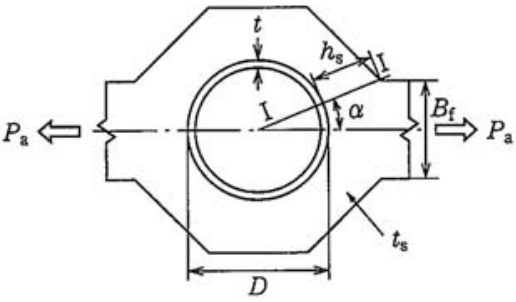

- Calculation method for steel socket tube ultimate strength

$$
\begin{aligned}
& M_{\mathrm{u}}=\left(v_{\mathrm{c}} \cdot f_{\mathrm{v}} \cdot \beta+1.2 v_{\mathrm{s}} \cdot \frac{f_{\text {sy }}}{\sqrt{3}}\right) \\
& v_{\mathrm{c}}: \text { Volume of filling mortar }\left(\mathrm{mm}^{3}\right) \\
& f_{\mathrm{v}}=\min \left(0.12 f_{\mathrm{c}}^{\prime}, 18+\frac{3.6 f_{\mathrm{c}}^{\prime}}{100}\right)
\end{aligned}
$$

$\beta$ : Modulus due to the beam-column joint form on the concrete-filled steel tubular 
column

$$
\beta=\min \left(2 \frac{D_{\mathrm{s}}}{d_{\mathrm{sb}}}, 4\right)
$$

$D_{\mathrm{s}}$ and $d_{\mathrm{sb}}$ are steel socket tube diameter and the beam flange centroid distance, respectively.

$v_{\mathrm{s}}$ : Volume of the joint panels $\left(\mathrm{mm}^{3}\right)$

$f_{\text {sy }}$ : Tensile yielding strength of the steel socket tube $\left(\mathrm{N} / \mathrm{mm}^{2}\right)$

Fig.20 and 21 compare experimental results and values calculated by Eq.(2) and (3) for the ultimate strength of joints. The experimental values exclude the positioning plate values estimated in the preceding section. Both figures show considerable disparities between calculated and experimental values. Fig.20 shows that Eq.(2) tends to acquire higher values than the experimental values, while Fig.21 shows that, with some exceptions, Eq.(3) tends to acquire lower values than the experimental values.

The reason for the disparities is that Eq.(2) and (3) were derived from tests on beam-column joints in which the external diaphragm is welded directly onto the concrete-filled steel tubular column, which differs from the current joint structure, leading to differing load bearing mechanisms. Also, Eq.(2) was derived on the basis of the idea that the T-shaped cross section produced from the external diaphragm and part of the wall of the steel tube serves to resist the force transmitted from the beam flange ${ }^{23)}$, but in the current joint, the steel socket tube outside the external diaphragm has been omitted. Therefore, the area in question has an L-shaped cross section, and the range of contribution of the steel tube wall also differs. Eq.(3) considers only the panel section of the steel socket tube in calculating ultimate strength, so it did not consider the effect of the external diaphragm. As described in the preceding chapter, the ultimate strength of this joint is realized because the steel socket tube and the external diaphragm form a mutual load bearing mechanism. Thus it appears that Eq.(3) would underestimate the experimental results. However, for specimens with large steel socket tube diameters, the reverse is true, as the calculated values exceed the experimental values. This occurs because Eq.(3) is such that ultimate strength increases with the volume of filling mortar, but the differences in load bearing mechanisms in this joint mean that the mechanism may not be as envisaged in the equation.

Thus the existing equation have failed to appropriately evaluate the ultimate strength of this joint. In the next and subsequent sections, we have proposed a new equation for calculating ultimate strength.

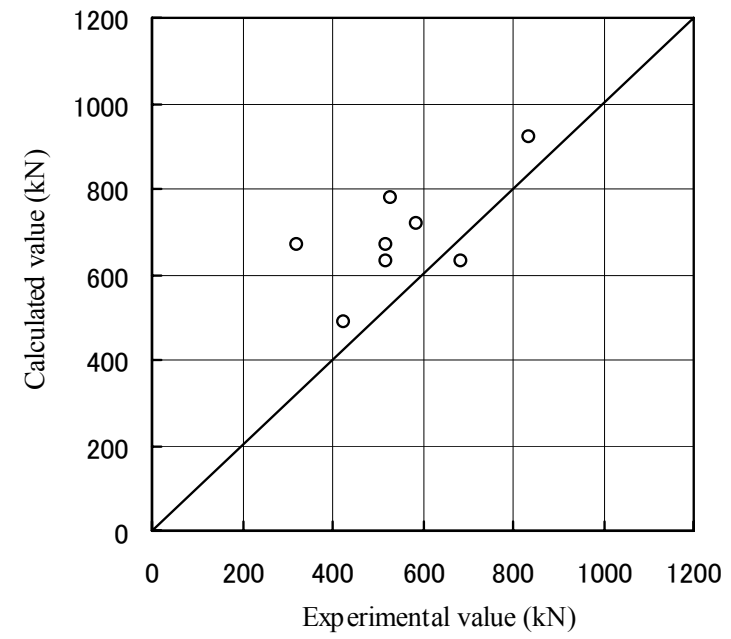

Fig.20 Comparison of Calculated and Experimental Values (Using the ultimate strength equation for the external diaphragm)

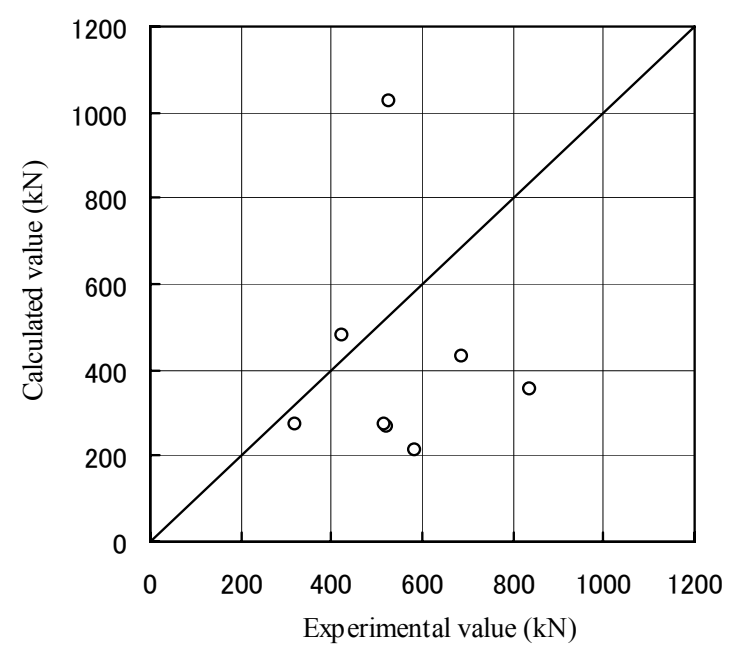

Fig.21 Comparison of Calculated and Experimental Values (Using the ultimate strength equation for the steel socket tube)

\section{(3)Consideration of a model to estimate the ultimate strength of $T$-shaped socket joints}

The failure processes for the joints investigated in the tests described above were observed, and consideration of principal strain distribution in the steel socket tube, strain distribution in the steel tube column and the effect of parameters related to load and displacement revealed that the main load bearing mechanism for the joint was that bending moment and shear force were resisted by a couple of forces caused by the bearing force between the steel tube column and the steel socket tube, a couple of forces caused by the frictional force between the steel tube column and the annular mortar fill, and the positioning plate. Therefore, we attempted to estimate the ultimate strength of the joint from the equilibrium of forces, assuming a load bearing model as shown in Fig.22. Ideally, the load bearing model should include the positioning plate, but the 


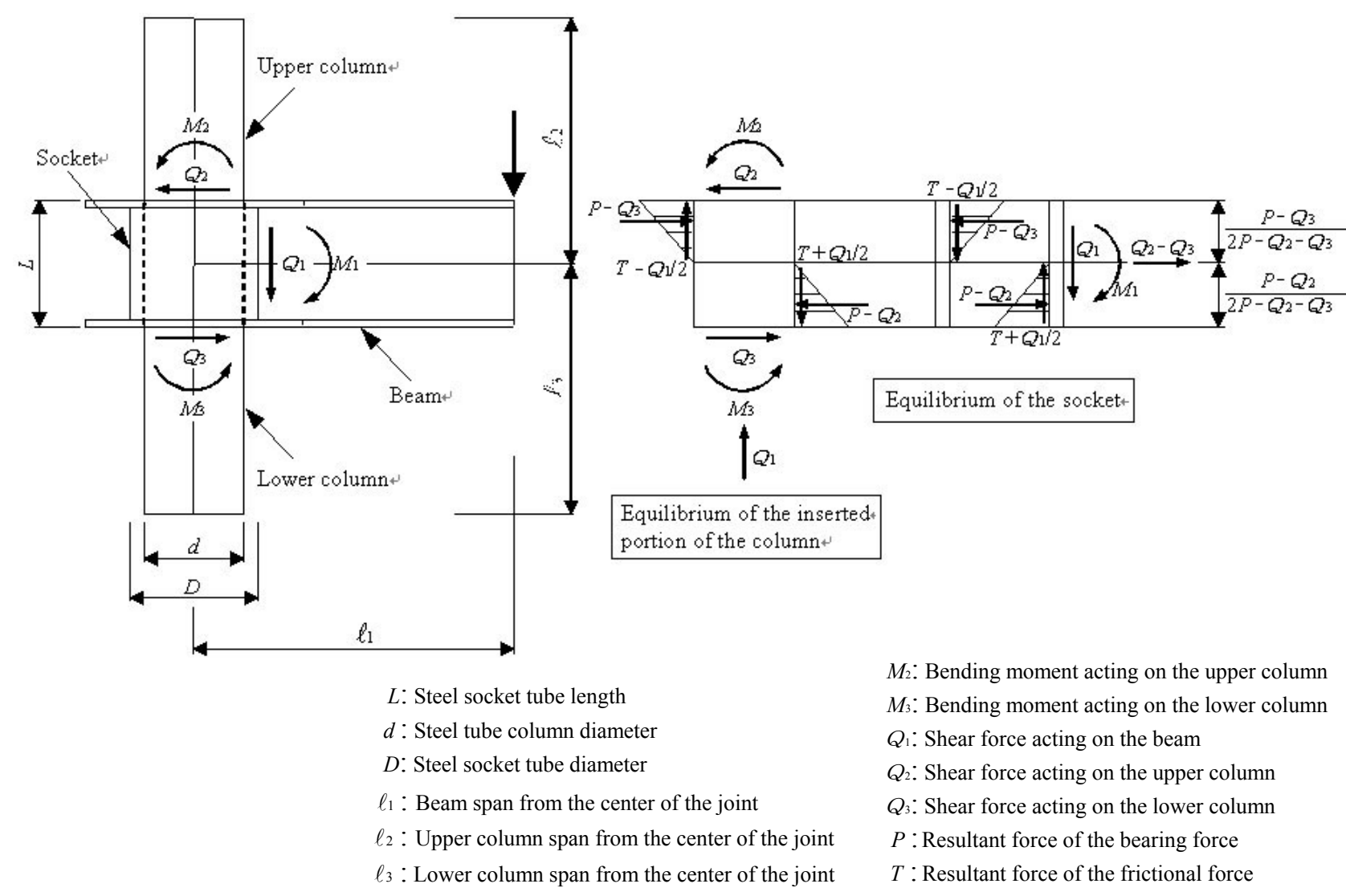

Fig.22 Load Bearing Model of the Joint

bearing strength of the positioning plate at the ultimate strength point differs according to the load bearing capacity of the socket joint, as shown in section (1). This experiment has been unable to clarify the division of strength between the positioning plate and the socket joint, so the load bearing model used excludes the positioning plate.

\section{a)Equilibrium equation of moment}

Eq.(4) is a equilibrium equation of moment for the model shown in Fig.22.

$$
\begin{aligned}
M_{1}+\frac{D}{2} Q_{1}-T\left(\frac{2 \sqrt{2}}{\pi}\right) d & =\left(P-Q_{3}\right) \frac{L\left(4 P-3 Q_{2}-Q_{3}\right)}{6\left(2 P-Q_{2}-Q_{3}\right)} \\
& +\left(P-Q_{2}\right) \frac{L\left(4 P-3 Q_{3}-Q_{2}\right)}{6\left(2 P-Q_{2}-Q_{3}\right)}
\end{aligned}
$$

where

$M_{1}$ : Bending moment acting on the beam $(\mathrm{N} \cdot \mathrm{mm})$

$Q_{1}$ : Shear force acting on the beam (N)

$Q_{2}$ : Shear force acting on the upper column (N)

$Q_{3}$ : Shear force acting on the lower column(N)

$T$ : Resultant force of the frictional force acting on the steel tube column $(\mathrm{N})$

$P$ : Resultant force of the bearing force acting on the steel tube column $(\mathrm{N})$

$d$ : Steel tube column external diameter (mm)
$D$ : Steel socket tube external diameter $(\mathrm{mm})$

$L$ : Length of the steel socket tube (mm)

Finding the maximum resultant frictional force $(T)$ and the maximum resultant bearing force $(P)$ from this moment equilibrium, it is possible to calculate the ultimate strength of the joint. At this stage, we assume that the frictional force between the column and the mortar acts uniformly over $1 / 4$ of the circumferential on the compression side of the column and $1 / 4$ of the circumferential on the tension side, reaching the maximum frictional force.

b)Resultant force of the frictional forces at the ultimate strength

The frictional force between the column and the mortar obeys Coulomb friction. Thus,

$$
\tau_{\max }=c+\sigma_{\text {ntan }} \phi
$$

where

$$
\text { c: cohesion }\left(\mathrm{N} / \mathrm{mm}^{2}\right)
$$

$\sigma_{\mathrm{n}}$ : normal stress on the boundary face $\left(\mathrm{N} / \mathrm{mm}^{2}\right)$

$$
\phi \text { : friction angle (rad) }
$$

Given the above, the resultant force of the frictional force (T) can be shown as the following equation:

$$
T=c \frac{\pi}{4} d L \frac{\left(P-Q_{2}\right)}{\left(2 P-Q_{2}-Q_{3}\right)}+\frac{\pi}{2 \sqrt{2}}\left(P-Q_{2}\right) \tan \phi
$$




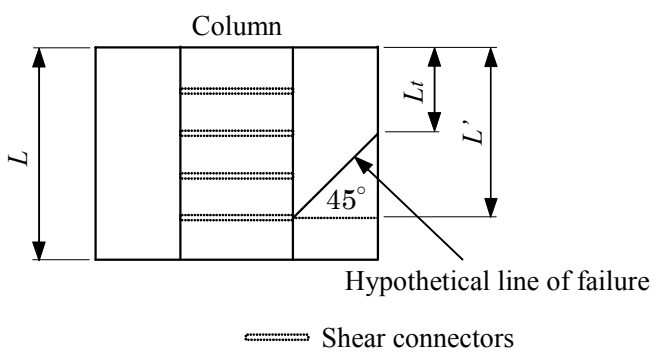

Fig.23 Failure Plane of Annular Mortar ${ }^{13), 14)}$

Studies to date ${ }^{13)}$ show that the frictional properties between a flat steel tube and concrete are such that $c=0.7\left(\mathrm{~N} / \mathrm{mm}^{2}\right)$ and $\phi=20^{\circ}$.

The ultimate bond strength between the steel socket tube and the mortar in the presence of shear connectors $\left(\tau_{\max }\right)$ can be calculated by Eq.(7) in accordance with the API standard ${ }^{21)}$. In this case, $T$ is found from Eq.(6), taking $\mathrm{c}=\tau_{\max }, \phi=0^{\circ}$.

$$
\tau_{\max }=1.15+1.72 f_{\mathrm{cu}}^{\prime} \cdot h / s
$$

where

$f^{\prime}{ }_{\mathrm{cu}}$ :The cubic specimen strength of the annular mortar $\left(\mathrm{N} / \mathrm{mm}^{2}\right)$ and the cylindrical specimen strength $f_{\text {cy }}^{\prime}$ is taken as $f^{\prime}$ cu $=f^{\prime}$ cy $10.8^{22)}$.

$h$ : Height of connectors (projections) $(\mathrm{mm})$

$s$ : Interval between connectors (mm)

\section{c)Resultant force of the bearing force at the} ultimate strength

According to reference 13), the resultant of bearing force acting on the column at the socket joint $(P)$ is assumed to be determined by the shear strength of the shear panel over the length $(L)$ of the steel socket tube (comprising the steel socket tube and the annular filling of mortar between the steel socket tube and the steel tube column). However, according to the results of the previous test, the ultimate strength of the joint appears to depend on a load bearing mechanism formed from the interaction of the steel socket tube and the external diaphragms. Therefore, the effect of the external diagrams must be considered in connection with the bearing force acting on the column. Therefore, the resultant of bearing force $(P)$ is assumed to follow the equation below.

$$
P=V_{\mathrm{s}}+V_{\mathrm{c}}+V_{\mathrm{p}}
$$

where

$V_{\mathrm{s}}$ : Shear force borne by the steel socket tube $(\mathrm{N})$

$V_{\mathrm{c}}$ : Shear force borne by the mortar $(\mathrm{N})$

$V_{\mathrm{p}}$ : Shear force borne by the external diaphragms $(\mathrm{N})$

First, the shear force borne by the panel of the steel socket tube when acted on by the bearing force $(P)$ is found from Eq.(9), taking it to be the pure shear
Table 4 Calculated and Experimental Values for Ultimate Strength

\begin{tabular}{|c|c|c|c|l|}
\hline $\begin{array}{c}\text { Specimen } \\
\text { name }\end{array}$ & $\begin{array}{c}\text { Experimental } \\
\text { value } \\
\text { Puexp } \\
(\mathrm{kN})\end{array}$ & $\begin{array}{c}\text { Calculated } \\
\text { value } \\
\text { Pucal } 1 \text { ( } \\
(\mathrm{kN})\end{array}$ & $\begin{array}{c}\text { Puexp } \\
\text { /Pucal } 1)\end{array}$ & \multicolumn{1}{|c|}{ Parameters } \\
\hline $\mathrm{P}-1$ & 522 & 555 & 0.94 & Standard case \\
\hline $\mathrm{P}-2$ & 426 & 555 & 0.77 & Steel socket tube diameter \\
\hline $\mathrm{P}-3$ & 837 & 758 & 1.10 & Steel socket tube length \\
\hline $\mathrm{P}-4$ & 686 & 602 & 1.14 & Steel socket tube thickness \\
\hline $\mathrm{P}-5$ & 586 & 586 & 1.00 & Steel socket tube diameter \\
\hline $\mathrm{P}-6$ & 517 & 592 & 0.87 & No positioning plate \\
\hline $\mathrm{P}-7$ & 321 & - & - & $\begin{array}{l}\text { No positioning plate, } \\
\text { no shear connectors }\end{array}$ \\
\hline $\mathrm{P}-8$ & 529 & 771 & 0.69 & Steel socket tube diameter \\
\hline
\end{tabular}

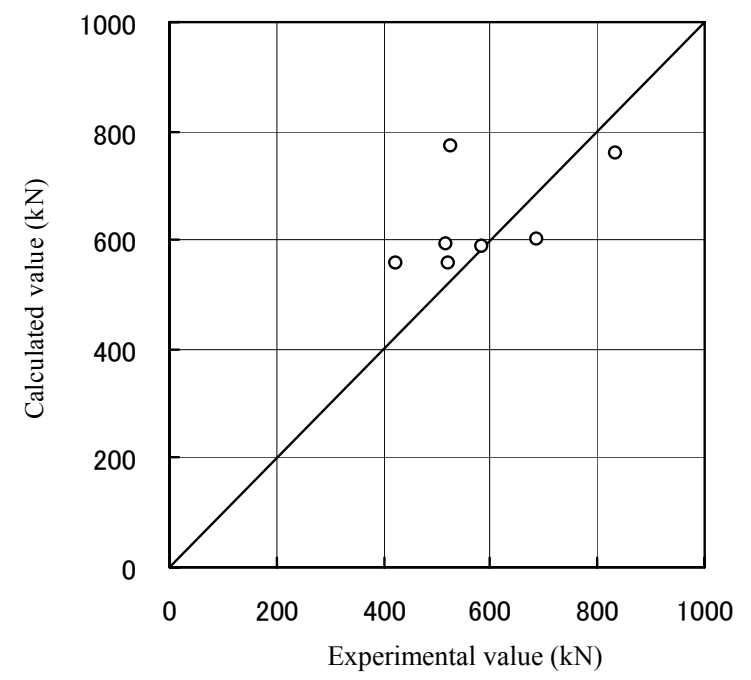

Fig.24 Comparison of Calculated and Experimental Values for Ultimate Strength

strength of the steel tube ${ }^{13)}$.

$$
V_{\mathrm{s}}=\frac{f_{\mathrm{sy}}}{\sqrt{3}} \frac{\pi(D-t) \cdot t}{2}
$$

where

$f_{\text {sy }}$ : Tensile yield strength of the steel socket tube $\left(\mathrm{N} / \mathrm{mm}^{2}\right)$

$t$ : Thickness of the steel socket tube (mm)

$D$ : Steel socket tube external diameter $(\mathrm{mm})$

Next, the shear force borne by the annular mortar is calculated from Eq. $(10)^{13), 14)}$.

$$
V_{\mathrm{c}}=\frac{3}{2 L}\left[\frac{\pi}{4} D_{\mathrm{i} L t c}\left(\frac{2 \sqrt{2}}{\pi} D_{\mathrm{i}}\right)-\frac{\pi}{4} d \frac{L}{2} c\left(\frac{2 \sqrt{2}}{\pi} d\right)\right]
$$

where

$D_{\mathrm{i}}$ : Internal diameter of the steel socket tube (mm)

$L_{t}$ : The length which contributes to the bonding force on the inside of the steel socket tube ( $\mathrm{mm}$, 

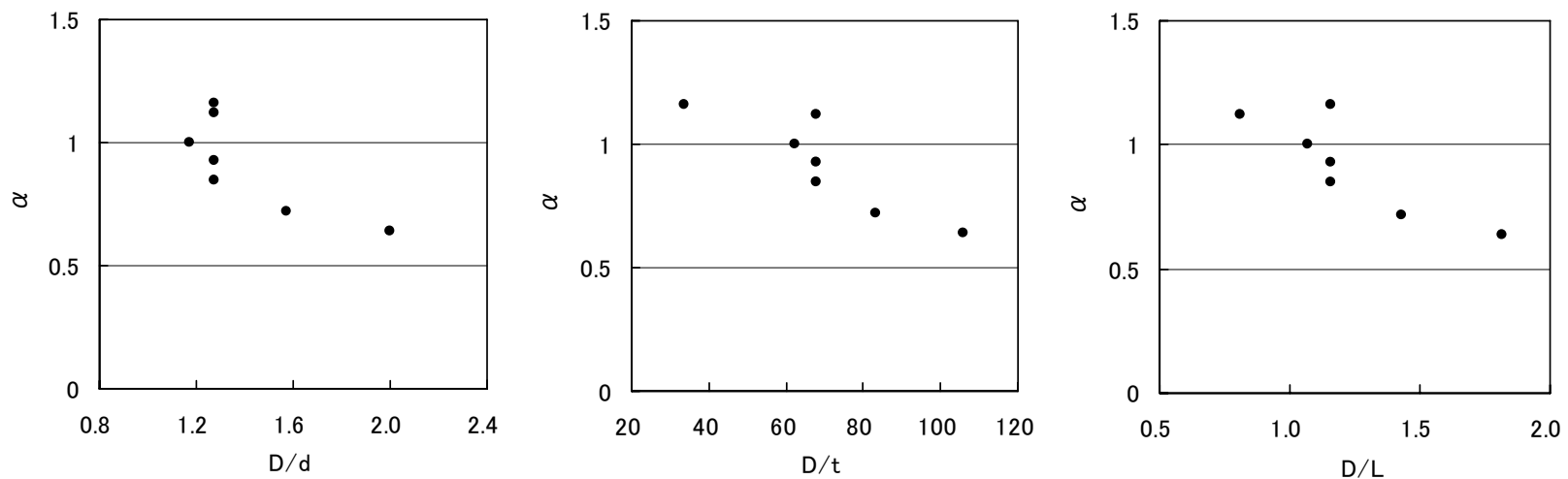

Fig.25 Relationship between Correction Coefficient $\alpha$ and Each Parameter

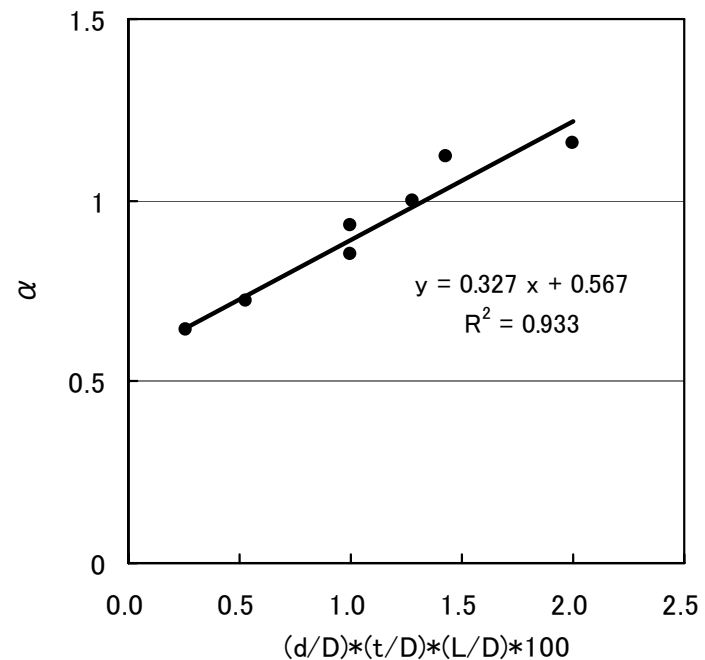

Fig.26 Relationship between Correction Coefficient $\alpha$ and the Parameters

see Fig.23).

$$
L_{t}=L^{\prime}-\left(D_{\mathrm{i}}-d\right) / 2
$$

The shear force borne by the external diaphragms is, according to reference 23), assumed to be as expressed in Eq.(11) (meanings of the terms are as in equation (2)).

$$
\begin{aligned}
V_{\mathrm{p}}= & f(\alpha) \cdot A_{1} \cdot f_{\mathrm{dy}} \\
& f(\alpha)=\frac{2}{\sqrt{3}} \sqrt{2 \sin ^{2} \alpha+1}
\end{aligned}
$$

The portion borne by the wall of the steel socket tube is calculated by Eq.(9), so only the portion borne by the external diaphragms is considered here.

\section{d) Calculation of ultimate strength}

Substituting the maximum frictional force $(T)$ and resultant bearing force $(P)$, as derived from Eq.(6) and Eq.(8), into the equilibrium equation of Eq.(4) and solving for $M$ gives the ultimate strength of the joint from the equation below.

$$
M \mathrm{u}=\frac{B-\sqrt{B^{2}-4 A C}}{2 A}
$$

where

$$
A=16 \ell_{1}^{2}\left[( \ell _ { 2 } + \ell _ { 3 } - L ) \left\{12 \ell_{2} \ell_{3}-2 \ell_{2} L-2 \ell_{3} L-L^{2}\right.\right.
$$

$$
\begin{aligned}
+ & \left.\left.3 d\left(2 \ell_{3}-L\right) \tan \phi\right\}+L\left(2 \ell_{2}-L\right)\left(2 \ell_{3}-L\right)\right] \\
B= & \left(2 \ell_{1}-D\right)\left(4 \ell_{2} \ell_{3}-\ell_{2} L-\ell_{3} L\right)\left[8 P \ell _ { 1 } \left(12 \ell_{2} \ell_{3}+\right.\right. \\
& \left.\ell_{2} L+\ell_{3} L-4 L^{2}\right)+6 \sqrt{2} d \ell_{1}\left\{c d L\left(2 \ell_{3}-L\right)+\right. \\
& \left.\left.2 \sqrt{2} P \tan \phi\left(3 \ell_{3}+\ell_{2}-2 L\right)\right\}\right] \\
C= & \left(2 \ell_{1}-D\right)^{2} \cdot\left(4 \ell_{2} \ell_{3}-\ell_{2} L-\ell_{3} L\right)^{2} . \\
& \left(8 L P^{2}+3 \sqrt{2} d^{2} c L P+12 d P^{2} \tan \phi\right)
\end{aligned}
$$

\section{(4)Comparison of experimental and calculated results}

Table 4 and Fig.24 compare calculated ultimate strength of a T-shaped joint, using the above equilibrium equation, against the experimental values. As specimen P-7 lacks shear connectors, the steel socket tube does not function as effectively as in other specimens and its load bearing mechanisms differ from other specimens. Therefore, it has been excluded from the comparison. Also, the experimental and calculated values exclude the effect of the positioning plate. The figure and table show considerable disparities between calculated and experimental values. This appears to be due to differences in shear stress distribution in the steel socket tube depending on whether a positioning plate is present, and differences in the division of strength between the steel socket tube and the external diaphragms due to differences in form, causing wide divergence in bearing force.

Therefore, we attempted to correct the resultant bearing force $(P)$ for Eq.(8) using the following equation:

$$
P=\left(V_{\mathrm{s}}+V_{\mathrm{c}}+V_{\mathrm{p}}\right) \cdot \alpha
$$

The correction coefficient $\alpha$ was estimated as described below. First, the ultimate strength was calculated using Eq.(12), then the correction coefficient $\alpha$ was calculated for each specimen where the result matched the experimental result. Then, the correlation between correction coefficient $\alpha$ and the test parameters was investigated. As a 
Table 5 Corrected Calculation Values and Experimental Values for Ultimate Strength

\begin{tabular}{|c|c|c|c|l|}
\hline $\begin{array}{c}\text { Specimen } \\
\text { name }\end{array}$ & $\begin{array}{c}\text { Experimental } \\
\text { value } \\
\text { Puexp } \\
(\mathrm{kN})\end{array}$ & $\begin{array}{c}\text { Calculated } \\
\text { value } \\
\text { Pucal(2) } \\
(\mathrm{kN})\end{array}$ & $\begin{array}{c}\text { Puexp } \\
\text { /Pucal(2) }\end{array}$ & \multicolumn{1}{|c|}{ Parameters } \\
\hline $\mathrm{P}-1$ & 522 & 504 & 1.04 & Standard case \\
\hline $\mathrm{P}-2$ & 426 & 434 & 0.98 & Steel socket tube diameter \\
\hline $\mathrm{P}-3$ & 837 & 777 & 1.08 & Steel socket tube length \\
\hline $\mathrm{P}-4$ & 686 & 715 & 0.96 & Steel socket tube thickness \\
\hline $\mathrm{P}-5$ & 586 & 576 & 1.02 & Steel socket tube diameter \\
\hline $\mathrm{P}-6$ & 517 & 538 & 0.96 & No positioning plate \\
\hline $\mathrm{P}-7$ & 321 & - & - & $\begin{array}{l}\text { No positioning plate, } \\
\text { no shear connectors }\end{array}$ \\
\hline $\mathrm{P}-8$ & 529 & 537 & 0.99 & Steel socket tube diameter \\
\hline
\end{tabular}

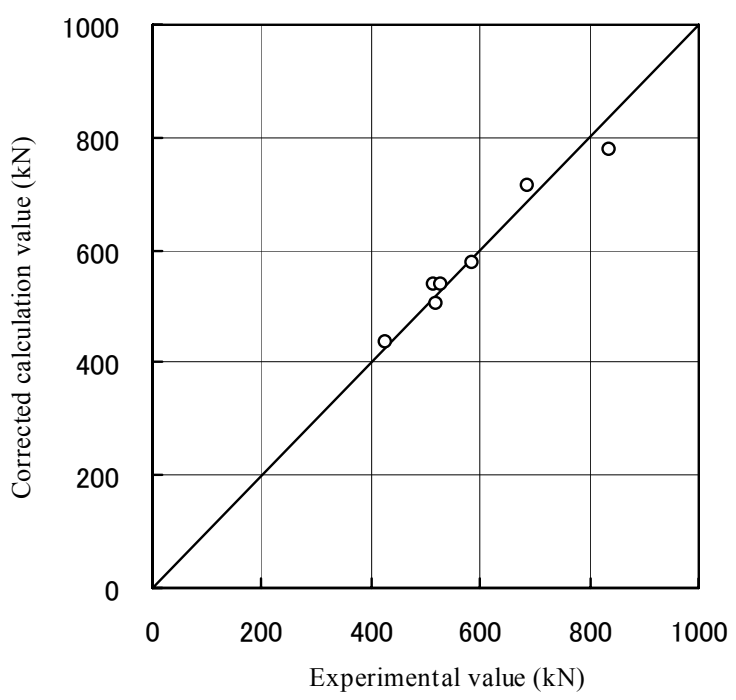

Fig.27 Comparison of Corrected Calculation Values and Experimental Values for Ultimate Strength

result, relatively strong correlations were observed with $D / d$, the ratio of column diameter $d$ to steel socket tube diameter $D, D / t$, the ratio between steel socket tube thickness $t$ and steel socket tube diameter $D$, and $D / L$, the ratio between steel socket tube length $L$ and steel socket tube diameter $D$, which are thought to be influential factors in the ultimate strength of the joint. Fig.25 shows a declining trend for the value of $\alpha$ with increasing size of $D / d, D / t$ and $D / L$. Fig.26 investigates the products of the reciprocals of $D / d$, $D / t$ and $D / L$. A largely linear relationship can be observed between correction coefficient $\alpha$ and the reciprocal product of $D / d, D / t$ and $D / L$, and correction coefficient $\alpha$ for ultimate strength can be formulated as in Eq.(14).

$$
\begin{gathered}
\alpha=0.327 X+0.567 \\
\text { where } \quad X=(d / D) \cdot(t / D) \cdot(L / D) \cdot 100
\end{gathered}
$$

Table 5 and Fig.27 compare the corrected calculated values for the ultimate strength of the joint, corrected as above for the resultant bearing force, against the experimental values. The calculated values evaluate the experimental values with a relatively high level of accuracy.

\section{CONCLUSIONS}

A socket type joint was applied to a beam-column joint and T-shaped model specimens were subjected to monotonic static loading tests. The results acquired the knowledge below, within the scope of the tests conducted. The ranges of test parameters were as follows:
$D / t: 33.8$ to 106.0
$D / d: 1.18$ to 2.00
$D / L: 0.81$ to 1.82
$L / d: 1.10$ to 1.57

where

$D:$ Steel socket tube diameter

$t$ : Steel socket tube plate thickness

$L$ : Steel socket tube length

$d$ : Steel tube column diameter

(1) The modes of failure of the joint were one estimated to be caused by tensile yielding of the external diaphragms and one estimated to be caused by shear yielding of the steel socket tube.

(2) The main load bearing mechanisms of this joint appear to be the couple of forces of the bearing force generated between the steel tube column and the steel socket tube, the couple of forces of the frictional force generated between the steel tube column and the annular mortar fill, and resistance by the positioning plate.

(3) The ultimate strength of the joint is due to a load bearing mechanism formed by the interaction of the steel socket tube and the external diaphragm. Therefore the mode of failure of the joint is controlled by which has the greater load bearing strength.

(4) The ultimate strength of the joint tends to decline as the steel socket tube diameter increases. This appears to be the case because the strength of the external diaphragms declines as the diameter of the steel socket tube is increased.

(5) The ultimate strength of the joint is strongly influenced by the thickness and length of the steel socket tube, and whether or not the joint includes a positioning plate and shear con- nectors.

(6) This study also presented an equation for estimating the ultimate strength of the joint, based on an assumed load bearing mechanism comprising a couple of bearing forces and a couple of frictional forces.

(7) The equation presented in this study for calculating the ultimate strength of the joint, 
eliminating the effect of the positioning plate, was able to evaluate the ultimate strength of the joints, as obtained experimentally in the tests, with a relatively high degree of accuracy.

This study proposed ultimate strength calculation equation of the joint based on monotonic loading tests, but further consideration of the effect of cyclic loading is required, and will be a task for future study. We will also test the applicability of the ultimate strength calculation equation proposed here to the cross-shaped joints.

ACKNOWLEDGMENT:In the course of this study, we received valuable assistance from Katsuhiko Osako and Tsutomu Hoshikawa of the Construction Technology Center of East Japan Railway Company, Construction Department. We are grateful for their cooperation.

\section{REFERENCES}

1) Murata, K., Yamada, M., Ikeda, M., Takiguchi, M., Watanabe, T. and Kinoshita, M.: Revaluation of Ductility for Concrete-filled Steel Tubular Columns, Proceedings of JSCE , No. 640/ I-50, pp.149-163, 2000.

2) Azuma, K., Sato, O. and Tada, H. : On the Planning of Rigid Frame Viaduct Applying Concrete-filled Steel Tubular Columns, Annual Conference of JSCE Tohoku Chapter (1995 edition), V-47, pp.610-611, 1995.

3) Fujita, S., Takano, H. and Konishi, H. : Design and Construction of the New Kamishiki Station (provisional name) on the Musashino Railway Line, Journal of Japan Railway Civil Engineering Association, 1996.

4) Iwata, S., Murata, K., Yamada, M. and Ishii, K. : Application of Concrete-filled Tubular Steel Columns to Railway Structures, Journal of Constructional Steel, Vol.7, pp.241-248, 1999.

5) Takiguchi, M. : The Design and Construction of the Hakozaki Overpass CFT Viaduct, Journal of Japan Railway Civil Engineering Association, 2000.

6) Tatsuki, S., Osato, T. and Yamada, M. : The Design of the Tohoku Shinkansen Line Daiichi Atago BL, Numakunai Bi, SED, JR East, No.15, 2000.

7) Hosaka, T. and Sugimoto, I. : Recent Steel-Concrete Hybrid Bridges for Railway Structures, Bridge and Foundation Engineering, Vol.34, No.7, 2000.

8) Inoue, T. and Sato, S. : Daiichi Shinden-Gawa Bridge-PC Hybrid Langer Bridge-, Bridge and Foundation Engineering, Vol.36, No.8, 2002.

9) Sato, S., Maruyama, T., Ito, A. and Suruga, M.: YokezawaGawa Bridge -Concrete-Filled Tubular Steel Simple String Arch Bridge with PRC Stiffening Girder-, Bridge and Foundation Engineering, Vol.36, No.8, 2002.

10) Hosaka, T., Mitsuki, K., Suzuki, Y. and Ichikawa, A : Study on Concrete Filled Tubular K-Joints of Truss Girder, Bridge and Foundation Engineering, Vol.36, No.8, 2002.

11) Railway Technical Research Institute: Model Code for Design of Hybrid Railway Structures, Maruzen, 1998.

12) Murata, K., Yasuhara, M., Kinoshita, M. and Kuzu, T. : Evaluation of Bearing Capacity of Joint Panels for Railway Mixed Structures, Steel Construction Engineering, Vol.5, No.19, pp.9-20, 1998.

13) Nozawa, S., Kinoshita, M., Tsukishima, D. and Ishibashi, T.: Ultimate Strength of Sleeve Joints between Concrete-filled Circular Steel Pipes, Proceedings of JSCE , No.606/V-41, pp.31-42, 1998.

14) Nozawa, S., Kinoshita, M., Tsukishima, D. and Ishibashi, T. : Ultimate Strength of Sleeve Joint between Concrete-filled Circular Steel Pipes with Shear Connector, Proceedings of JSCE, No.634/V-45, pp.71-89, 1999.

15) Architectural Institute of Japan : Standard for Structural Calculation of Steel Reinforced Concrete Structures, 2001.

16) Takayama, T., Murata, K., Ikeda, M. and Kinoshita, M.: A Design Method of Beam-to-Column Insert Joint for Hybrid Railway Rigid Frame Elevated Bridges, Proceedings of JSCE ,No.703/I-59, pp.151-163, 2002.

17) Yamada, M., Nishizawa, M. and Okano, M. : Three Dimensional F.E.M. Analysis and Loading Tests of Joint Panel of Concrete Filled Steel Tubular Columns and Reinforced Concrete Beam, Journal of Structural Engineering, JSCE, Vol.49A, pp.1029-1039, 2003.

18) Kudo, S., Takagi, Y. and Kinoshita, M. : Experimental Study on L-Shaped Beam-Column Socket Joints, Proceedings of 51th Annual Conference of JSCE, I-A218, pp.434-435, 1997.

19) Kobayashi, H., Furuya, T. and Kinoshita, M. : Strength Tests on Cross-Shaped Beam-Column Socket Joints, Proceeding of 24th Annual Conference of JSCE Kanto Chapter, V-13, pp.582-583, 1997.

20) Yamada, M., Hayashi, A. and Nozawa, S.: Experimental Study on Sleeve Joint between Steel Beam and Concrete-filled Steel Tubular Column, Proceedings of the Japan Concrete Institute, Vol.25, pp.1,597-1,602, 2003.

21)American Petroleum Institute : Recommended practice for planning, designing and constructing fixed offshore platforms, APIRP2A, 19th Edition, 1991.

22) Murata, J., Kokubu, K. and Tsuji, Y.: Simplified Civil Engineering Course 10, New Third Edition, Concrete Engineering (I) Construction, Shokokusha, 1993.

23) Kurobane,Y., Togawa, T. and Matsuo, O.: Beam-to-Concrete Filled Tubular Column Connections with Stiffener Rings, Parts 1 to 3, Summaries of Technical Papers of Annual Meeting Architectural Institute of Japan, pp.1275-1280, 1987.

(Received May 15, 2005) 